Portland State University

PDXScholar

7-20-1993

\title{
The Natural Approach and the Audiolingual Method: A Question of Student Gains and Retention
}

Jeffrey Robert Richards

Portland State University

Follow this and additional works at: https://pdxscholar.library.pdx.edu/open_access_etds

Part of the Bilingual, Multilingual, and Multicultural Education Commons Let us know how access to this document benefits you.

\section{Recommended Citation}

Richards, Jeffrey Robert, "The Natural Approach and the Audiolingual Method: A Question of Student Gains and Retention" (1993). Dissertations and Theses. Paper 4696.

https://doi.org/10.15760/etd.6580

This Thesis is brought to you for free and open access. It has been accepted for inclusion in Dissertations and Theses by an authorized administrator of PDXScholar. Please contact us if we can make this document more accessible: pdxscholar@pdx.edu. 


\section{THESIS APPROVAL}

The abstract and thesis of Jeffrey Robert Richards for the Master of Arts in Teaching English as a Second Language were presented July 20, 1993, and accepted by the thesis committee and the department.

COMMITTEE APPROVALS:
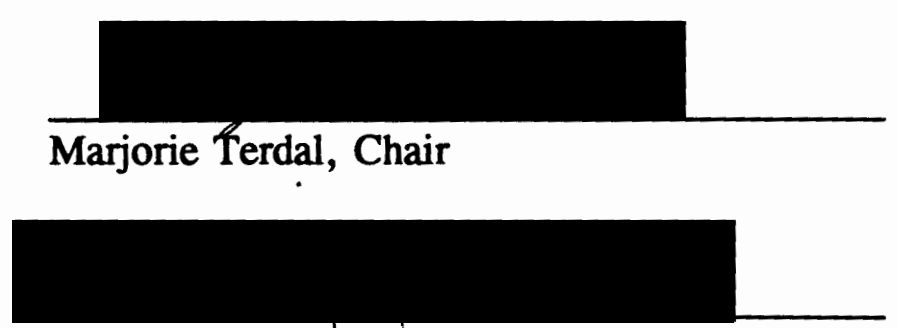

Kimberley A. Błown

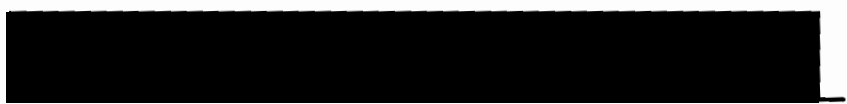

Earl L. Rees

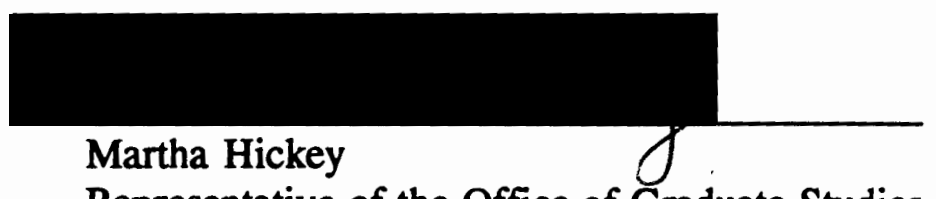

Representative of the Office of Graduate Studies

DEPARTMENTAL APPROVAL:

Chepartment of Applied Linguistics

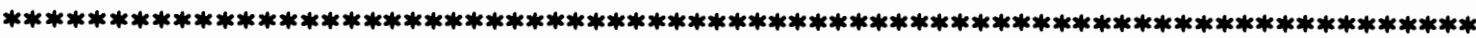

\section{ACCEPTED FOR PORTLAND STATE UNIVERSITY BY THE LIBRARY}

by

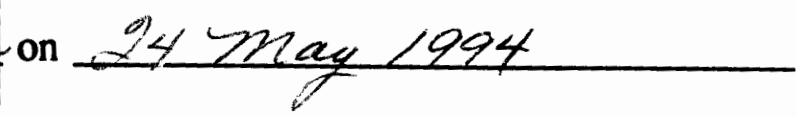




\begin{abstract}
An abstract of the thesis of Jeffrey Robert Richards for the Master of Arts in Teaching English as a Second Language presented July 20,1993.
\end{abstract}

Title: The Natural Approach and the Audiolingual Method: A Question of Student Gains and Retention.

The purpose of this study was to determine the difference in the short term and and long term second language (L2) gains of first year Spanish students exposed to the Audiolingual Method (ALM) and the Natural Approach.

The experiment consisted of two randomly selected groups which were exposed to four presentations. Two of these presentations delivered content material following a Natural Approach lesson design while the other two delivered content material following an ALM lesson design in such a way that both groups were exposed to two ALM lessons ane two Natural Approach lessons. All subjects were pre-tested prior to the delivery of these lessons and subsequently tested after the first lessons for short term L2 gains. They were then re-tested after several weeks to measure long term L2 gains. The number of subjects that participated in the experiment was 249 and included all enrolled first year Spanish students at Oregon State University for the 1992 fall term. The data were analyzed using the two-way analysis of variance. 
The results of the investigation indicated that teaching method was not a significant factor in students' short term and long term L2 aquisition gains. The study thus implies that neither the Natural Approach nor the ALM can be considered superior in terms of quantifiable student gains and retention.

Recommendations for further study are presented. 
THE NATURAL APPROACH AND THE AUDIOLINGUAL METHOD: A QUESTION OF STUDENT GAINS AND RETENTION

\author{
by \\ JEFFREY ROBERT RICHARDS
}

A thesis submitted in partial fulfillment of the requirements for the degree of

MASTER OF ARTS

in

TEACHING ENGLISH AS A SECOND LANGUAGE

Portland State University

1993 


\section{ACKNOWEDGEMENTS}

The investigator wishes to express his appreciation to the individuals who gave assistance to this research project. First, a special note of gratitude is extended to the Chair of my thesis committee, Dr. Marjorie Terdal, who provided many suggestions vital to this study as well as guidance and support. My appreciation is also extended to the

other members of my committee, Dr. Kimberley A. Brown, Dr. Martha Hickey and Dr. Earl L. Rees.

I am grateful for the support of Krista Tyson, whose assistance, observations and statistical expertise helped to make this project possible.

I would also like to thank the Spanish 111 teaching assistants from the fall term, 1992, for their cooperation in the implementation of this study.

Finally, I wish to extend my appreciation to the Oregon State University Department of Statistics and its Consulting Service Program. 
TABLE OF CONTENTS

PAGE

ACKNOWLEDGEMENTS $\ldots \ldots \ldots \ldots \ldots \ldots \ldots \ldots$ iii

LIST OF TABLES $\ldots \ldots \ldots \ldots \ldots \ldots \ldots \ldots$

CHAPTER

I INTRODUCTION $\ldots \ldots \ldots \ldots \ldots \ldots$

Background of the Problem $\ldots \ldots \ldots \ldots$

Rationale, Significance, Need for the Study . . . . . . 3

Questions $\ldots \ldots \ldots \ldots \ldots \ldots$

Definition of Terms $\ldots \ldots \ldots \ldots \ldots$

II REVIEW OF LITERATURE $\ldots \ldots \ldots \ldots \ldots$

Theoretical Observations $\ldots \ldots \ldots \ldots \ldots$

Experimental Evidence $\ldots \ldots \ldots \ldots \ldots 18$

Critique of Validity of Research Literature . . . . 21

III RESEARCH PROCEDURES AND DESIGN . . . . . 26

Method ................. 26

Subjects $\ldots \ldots \ldots \ldots \ldots \ldots \ldots$

Procedures . . . . . . . . . . . . . 28

Instrumentation $\ldots \ldots \ldots \ldots \ldots \ldots$ 
IV RESULTS $\ldots \ldots \ldots \ldots \ldots \ldots \ldots \ldots \ldots \ldots$

Dependent Variables $\ldots \ldots \ldots \ldots \ldots \ldots \ldots 38$

Independent Variables $\ldots \ldots \ldots \ldots \ldots \ldots$

Statistical Analysis . . . . . . . . . . 39

V DISCUSSION ................. 49

Summary of Research . . . . . . . . . 49

Discussion of the Research Results ... . . . . 49

Limitations to the Study $\ldots \ldots \ldots \ldots \ldots \ldots 6$

Recommendations for Further Study . . . . . . 58

Conclusions and Implications $\ldots \ldots \ldots \ldots \ldots 60$

REFERENCES $\ldots \ldots \ldots \ldots \ldots \ldots \ldots \ldots \ldots \ldots \ldots \ldots \ldots \ldots \ldots \ldots \ldots$ APPENDICES

A SAMPLE NATURAL APPROACH LESSON PLAN ...65

B SAMPLE ALM LESSON PLAN $\ldots \ldots \ldots \ldots \ldots 7$

C INFORMED CONSENT FORM $\ldots \ldots \ldots \ldots \ldots 73$

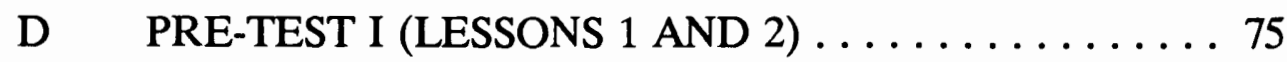

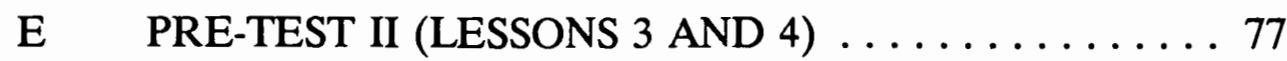

F TEST I (LESSONS 1 AND 2) ........... 79

G TEST II (LESSONS 3 AND 4) $\ldots \ldots \ldots \ldots \ldots \ldots$

H POST-TEST I (LESSONS 1 AND 2) $\ldots \ldots \ldots \ldots$

I POST-TEST II (LESSONS 3 AND 4) $\ldots \ldots \ldots \ldots$ 


\section{LIST OF TABLES}

TABLE

PAGE

I Method of Presentation of Natural Approach and ALM

Lessons to Experimental Groups . . . . . . . . 25

II Pre-test and Test Mean Scores and Standard Deviations

Using the Natural Approach Teaching Method . . . . 40

III Pre-test and Test Mean Scores and Standard Deviations

Using the ALM Teaching Method $\ldots \ldots \ldots 40$

IV Teaching Assistants: Comparison of Pre-test and Test

Mean Scores $\ldots \ldots \ldots \ldots \ldots \ldots \ldots$

V Comparison of Mean Scores and Standard Deviations

for Pre-test and Test for Lessons 1 Through 4

Within Group A . . . . . . . . . 43

VI Comparisons of Mean Scores and Standard Deviations

for Pre-test and Test for Lessons 1 Through 4

Within Group B ............. 43

VII Pre-test and Post-test Mean Scores and Standard Deviations

Using the Natural Approach Teaching Method . . . . 45

VIII Pre-test and Post-test Mean Scores and Standard Deviations

Using the ALM Teaching Method $\ldots \ldots \ldots \ldots 45$ 
IX Teaching Assistants: Comparison of Pre-test and Post-test

Mean Scores $\ldots \ldots \ldots \ldots \ldots \ldots \ldots \ldots$

X Comparison of Mean Scores and Standard Deviations

for Pre-test and Post-test for Lessons 1 Through 4

Within Group A ............ 47

XI Comparison of Mean Scores and Standard Deviations

for Pre-test and Post-test for Lessons 1 Through 4

Within Group B . . . . . . . . . . 47 


\section{CHAPTER I}

\section{INTRODUCTION}

\section{BACKGROUND OF THE PROBLEM}

The second language (L2) instructor is currently faced with a great choice of communicative teaching methodologies which are intended to reflect natural language acquisiton. Some of these choices, such as the Silent Way (Gattegno), Total Physical Response (Asher), Community Language Learning (Curran), Suggestopedia (Lozanov), and the Counseling Learning Model (based on Curran's methods), represent rather rigid and firm guidelines as to how a L2 instructor should go about with natural, communicative instruction (Richards \& Rogers, 1987).

A less rigid and more innovative approach can be found in Terrell's (Krashen \& Terrell,1983) Natural Approach. The Natural Approach, based on the language acquisition and learning hypotheses of Steven Krashen, presents a basic way in which personal communicative skills are mastered. The focus is on real communication in natural situations, and unlike some of its more rigid counterparts, represents more of a sense than an approach (Krashen \& Terrell,1983). By utilizing the Natural Approach, a L2 instructor may choose authentic, appropriate materials and structure such materials to meet the particular needs of L2 students. Combinations of interactive activities are advocated, and rather than precluding the communicative activities of other 
methodologies, the Natural Approach actually encourages the incorporation of such activities when deemed appropriate.

The choices facing a L2 instructor today are based on linguistic theories that propose that first language acquisition (L1) is similar to $\mathrm{L} 2$ acquisition. Futhermore, an instructor should be aware that according to Krashen's theory, learning represents a conscious effort on the student's part and differs from acquisition, which represents an unconscious effort on the student's part and more closely reflects $\mathrm{L} 1$ acquisition. In the 1950's and 1960's, the popular method in second language teaching represented a more unified body of both theory and practice (Long \& Richards, 1987). This method, known as the Audiolingual Method (ALM), represented a more rigid approach to second language learning, and was based on contrastive analysis, pattern drills and repetition. Philosophically, the ALM had its roots in Behaviorism and was born from necessity during the Second World War. As many multilingual people were needed for the war effort, the United States Army Language Program was initiated and began to train personnel in a way consistent with Behaviorism. This method, later to become known as the ALM, was furthered in importance and acceptance in 1958, when the Congress of the United States passed the National Defense Education Act. The ALM thus proceeded to become entrenched as the standard method of second language instruction in the United States.

The ALM was not, however, without its critics. Criticisms leveled included the slow nature of habit formation (a central theme to the ALM) and the lack of comprehension by students of what they were saying in constant repetition drills (Krashen 
$\&$ Terrell, 1983). Thus, new methods which emphasized communication and language acquisition were developed. These new methodologies, however, have not completely supplanted the Audiolingual Method. As the ALM was used so widely for so many years, many adaptations of the ALM are still in use today (Brown, 1987). For example, the text Hablamos Español, which is currently used as a first year Spanish text at Oregon State University, incorporates many characteristics of the ALM.

\section{RATIONALE, SIGNIFICANCE, NEED FOR THE STUDY}

Although the majority of educational theorists do advocate the use of L2 teaching methods that foster communicative competence, it is far from certain that such methods are actually in use in L2 classroom settings today. In fact, Yeats (1985) believes it is quite likely that the majority of teachers are currently still using a basic ALM approach. Some L2 instructors today may also simply augment a basic ALM course design with a few communicative activities and consider their approach as communicative when in reality it still holds true to most of the tenets of the ALM. Thus, despite theoretical evidence that sheds doubt upon the ALM's efficacy as a L2 teaching method, there seems to be reluctance by some instructors to forego this method and adopt a more communicative approach.

Part of the aforementioned hesitancy by L2 instructors in adopting a communicative approach could come about in part by contemporary proponents of the ALM who criticize the Natural Approach and other communicative approaches to language learning. A major tenet of the ALM is its use of frequent repetition and group 
recitals, which may or may not contain units of comprehensible input. ALM proponents maintain that such recitals raise the level of students' motivation, and thus encourage effective L2 acquisition. They also suggest that frequent repetition of words, sentences and morphological components will ultimately lead to L2 mastery (Donovan,1985).

Critics of the Natural Approach also maintain that L2 students may not be given opportunity to produce enough output following the Natural Approach, nor will they achieve any progress because the Natural Approach emphasizes little overt correction (Swain,1988). ALM proponents believe that ALM exercises will prepare students for the "real-world nature of language needs", and some have even charged that the Natural Approach is little more than a revamped Direct Method Approach (Donovan,1985). Indeed, some critics have charged that the Natural Approach exposes L2 students to the dangers of "fossilizing grammatical errors" due to its lack of overt error correction (Higgs \& Clifford, 1982).

The Natural Approach is thus not above citicism in the theoretical realm. This study proposes to go beyond the attempts to address the theoretical differences and controversies surrounding these two L2 teaching approaches, and will attempt to systematically and empirically compare these aproaches in a classroom environment. As very few such systematic studies between the Natural Approach and the ALM have been conducted, it is clear that such a study is warranted (Chamot,1985). Although most theorists today contend that communicative methods are more effective, it is nevertheless thought that "the empirical basis of these approaches is insufficient and that more experimentation is needed" (Nicola, 1990). Furthermore, it is charged that even though 
the ALM approach has met with little success, its methodology still has not been adequately field tested (Krashen \& Terrell,1983). No method can thus be called best in an absolute sense (Martin \& Molero,1984); consequently, I believe that there is a need for such a comparative study.

It has been purported that the ALM has not been successful as it deals with language structure and not language acquisition (Krashen \& Terrell,1983). As the Natural Approach is based on current theories of L2 acquisition, it is reasonable to assume that the Natural Approach will be more successful that the ALM. This is the assumption I would like to test in this study.

\section{QUESTIONS}

There have been many shifts over the years in regard to second language learning and acquisition. Today we favor communicative approaches, such as the Natural Approach, over the ALM. Nevertheless, questions still remain regarding the effectiveness in terms of student gains of both the Natural Approach and the ALM. The major question to be addressed in this thesis thus deals with measurable and quantifiable student gains made by using the Natural Approach as opposed to the ALM.

Steven Krashen (1990) considers 'comprehensible input' to be the most important causative variable in L2 acquisition. Thus, an approach such as the Natural Approach should be more successful than an approach which does not provide meaningful input. Krashen further states that communicative methods such as the Total Physical Response (TPR) are much better than the ALM and cites studies by Asher (1982) and 
Swaffer/Woodward (1978) which support this hypothesis. Nevertheless, Krashen also admits that most comparision studies that examine such approaches do not expressly show significant differences in student gains. It would thus be interesting to see if an experimental study could indeed show such differences for both short term as well as long term student L2 gains.

Research Question 1

Are short term L2 gains of students exposed to a Natural Approach lesson design superior to the short term L2 gains of those students exposed to an ALM lesson design?

Hypothesis 1

Students who are exposed to L2 content material using a Natural Approach lesson design will outperform those students who are exposed to the same content material using an ALM lesson design in quantifiable test score gains.

\section{$\underline{\text { Research Question } 2}$}

Are long term L2 gains of students exposed to a Natural Approach design superior to the long term L2 gains of those students exposed to an ALM lesson design?

\section{Hypothesis 2}

Students who are exposed to the same content material using a Natural Approach lesson design will outperform those students who are exposed to the same content material using an ALM lesson design in quantifiable test score gains. 


\section{DEFINITION OF TERMS}

Audiolingual Method (ALM): A L2 instructional method that stresses an inductive presentation of content material with extensive pattern practice, drills, repetition and examples through contrast.

Behaviorism: A school of thought which maintains that nothing is truly scientific without empirical knowledge and that all learning is a matter of conditioning or the formation of habits due to outside stimuli.

Cognitive Competence: The ability to comprehend and to use language as a set of rules and not by simple habit formation (Celce-Murica, 1979).

Communicative Approach: A L2 teaching approach which stresses comprehensible input as an essential ingredient in language acquisition (Krashen,1991).

Communicative Competence: The use of native speakers' internalized grammar or 'competence' underlying language use at grammatical, discourse and sociolinguistic levels (Campbell, 1979).

Communicative Tests: Tests which are pragmatic and require the ability to demonstrate language use in a wide variety of language functions with an acceptable level of appropriateness (Wesche,1987).

Comprehensible Input: Input by which one acquires language that has meaning (Krashen, 1990).

Discourse Competence: The ability to use larger linguistic units of language appropriately.

Drills: L2 exercises which are designed to manipulate meaningful content material in 
order to establish a pattern. New structures are presented by means of repetition, substitution, completion or expansion (Larsen-Freeman, 1979).

Group Recitals: Given a stimulus from an instructor, students follow drills in unison. Natural Approach: A L2 teaching approach based on Krashen's theoretical hypotheses in which comprehension precedes production, production is allowed in stages, communicative goals and course design are based on the presentation of information slightly above students' L2 acquisition levels, and students' anxiety levels or 'affective filters' are lowered.

Sociolinguistic Competence: The ability to use language in the proper context in interactive and social functions. 


\section{CHAPTER II}

\section{REVIEW OF LITERATURE}

\section{THEORETICAL OBSERVATIONS}

The choices facing a L2 instructor today are based on linguistic studies indicating that first language acquisition (L1) is similar to L2 acquisition. Thus, it would be reasonable to assume that a $\mathrm{L} 2$ learning approach that reflects language acquisition rather than language structure would be most effective in a L2 classroom. The Natural Approach, which is based on current theories of L2 acquisition, would appear to be an ideal approach (Krashen \& Terrell,1983). Krashen and Terrell (1983) indicate that, since ALM approaches have not met with great success, many L2 instructors are searching for a new, communicative approach to L2 learning based on the understanding of comprehensible input.

Although there has been much discussion concerning the nature of L2 acquisition, there is still no unified communicative approach to $\mathrm{L} 2$ instruction. Many theorists in fact maintain that no method is best in an absolute sense as it must be suited to learners' aptitudes, needs, interests, levels and time available (Martin-Molero,1984). Additudinal variables as well as the age of the L2 student are factors which could influence the chosen method of L2 instruction (Krashen \& Terrell,1983). Furthermore, while the majority of theorists advocate communicative competence, the majority of classroom 
instructors are still using a basic ALM course design (Yeats, 1985).

A complete shift from the ALM to a communicative approach to L2 learning is further hindered by theorists who disagree with the basic premise of such an approach. For example, Higgs and Clifford (1982) stress that before students engage in communicative activities, students must first have acquired the necessary grammatical rules. If such rules are not acquired before being placed in a 'free' conversational setting, there could be a danger of fossilizing grammatical errors. A communicative approach which is inductive and does not rely on overt correction of student errors (such as the Natural Approach) could lead students to internalize incorrect grammatical patterns. Parkin (1991) also maintains that insufficient corrective feedback from L2 teachers could lead to fossilization and that error correction should be used in order for students to correct fossilized structures. Furthermore, in a study done with speakers of English in Quebec, Canada, it was found that grammatical errors were fossilized in a communicative setting (Parkin,1991). Nevertheless, the causes of fossilization are not definite and could very well be due to a combination of several factors, such as the application of false leamer hypotheses, neurolinguistic or sociolinguistic factors, as well as the lack of overt correction of student errors (Sims, 1989).

Similar reservations are echoed by Swain (1988), who objects to the Natural Approach's lack of overt correction as well as the lack of student output during the initial 'silent period'.

The ALM, on the other hand, stresses repetitive drills, mimicry and dialog presentation. Reinforcement of correct responses and correction of student errors in 
pronunciation are important and students are constantly involved in L2 output (CelceMurcia,1979). And although the ALM does rely heavily on student output and oral production, it is important to note that both approaches follow the same order of skill acquisition in that oral production precedes written production (Chamot,1985).

Further obstacles to the complete shift from the ALM to a communicative L2 learning approach comes from theorists who still support basic ALM tenets and question the efficacy of communicative approaches. Donovan (1985), for example, finds theoretical flaws with the natural approach because it ignores characteristics of children's language learning process. He charges that the belief that explicit error correction is ineffective is a theory not firmly established and that frequently used words, sentences and morphological components should be mastered and frequently reviewed so as to confront the random nature of real-world language needs. The ALM is not a failure as Krashen would maintain, according to Donovan, but is a viable approach which only requires the addition of a communicative element in order to be an effective L2 approach (Donovan, 1985).

Due to the large volume of criticism directed at the ALM, a proposed shift from the ALM to a communicative approach has been advocated by many researchers and theorists (Asher,1982; Hammond,1988; Krashen \& Terrell,1983; Mayer, 1985; Nicola, 1990; Savignon,1982). The most obvious criticism of the ALM is that it has not met with great success in the classroom (Krashen \& Terrell,1983). Further criticism argues that the ALM's inception was based on faulty linguistic and psychological models and that by the 1960 's it was apparent that the ALM was not producing fluent L2 
students (Hammond, 1988). Hammond (1988) has even gone on to charge that the ALM is nothing more than a revamped repetition of the grammar-translation model, which does not even begin to address the realities of language acquisition theory.

It may be interesting to investigate at this time why $\mathrm{L} 2$ instructors would be reluctant to abandon a basic ALM design, given that most theorists clearly favor a more communicative design. Part of the answer may lie in the simplicity of the ALM technique. The ALM is an easy approach for L2 instructors to learn and an easy approach to use with students (Chamot,1985). Using the ALM approach, an instructor models correct sentences and makes use of repetition, substitution and pattern drills. Model sentences then become fixed in the students' memory and can be retrieved whenever the students need such a sentence. Unfortunately, such 'simplicity' has not been supported by recent studies in lingusitics, pyschology and pedagogy (Chamot,1985).

Further complicating the acceptance of a true communicative approach to L2 acquistion in the classroom environment is that although many instructors favor such an approach and are dedicated to its implementation, they are not themselves properly trained in the tenets of communicative approaches and thus continue to use a basic ALM course design while believing such a course design to be communicative (Yeats, 1985).

Although many theorists agree that communicative methods are effective, there is still not a clear consensus based on experimental evidence. Further experimentation is thus warranted (Nicola, 1990).

\section{Tenets of the ALM}

The ALM was conceived from the theories of behavioral psychologists and their 
contemporaries in linguistics, the Structuralists (Larsen-Freeman, 1979). The Behaviorists believed that nothing could be considered truly scientific except knowledge which could be physically measured and observed (Newton,1979). The Structuralists applied such theories to the linguistic realm and believed language to be a sequence of discrete units (Larsen-Freeman,1979). From such theories evolved the ALM, which emphasized dependence on mimicry, memorization of set phrases and the mastery of sequenced structures (Prator \& Celce-Murcia, 1979).

The United States military was first to embrace the ALM in intensive language courses intended to train military personnel quickly in a wide variety of languages during the Second World War. This program was known as the Army Specialized Training Program and later became known as the ALM in the 1950's (Brown,1987). At this time the ALM gained acceptance in the United States by L2 instructors to such a degree that it had been referred to as the 'orthodoxy' of audiolingualism (Richards \& Rogers, 1987). Advocates of the ALM (Brooks, 1964; Lado,1964) were instrumental in the wide acceptance and usage of the ALM in the 1960's.

The basic tenet of the ALM is that "language consists of a set of habits in the use of language structures and patterns" (Krashen \& Terrell,1983,p.14). Just as the view of language as a set of habits was consistent with the ALM's theoretical roots in Behaviorism, so was the ALM's emphasis on exposure, imitation and positive or negative reinforcement of student responses. Adults were thought to acquire the 'habits' of their native language ( $\mathrm{L} 1$ ) and thus they were expected to acquire new 'habits' of the target language. Error correction therefore became essential to the ALM as an aid to help 
adults overcome L1 interference, which was considered to be a set of 'bad habits' (Larsen-Freeman, 1979).

The ALM utilizes an inductive approach to L2 learning in which an instructor presents examples from which the student induces a L2 rule (Larsen-Freeman, 1979). Therefore, instead of grammatical or rule explanations, an instructor using an ALM approach would present L2 content material using dialogue memorizations, pronunciation exercises, pattern practice and structural drilling. Repetition is paramount to the ALM (i.e., from the Behaviorist 'conditioning'), and thus the 'overlearning' of L2 content material is advocated (Larsen-Freeman,1979). L2 skills are sequenced in the ALM so that students will first concentrate on listening skills, followed by speaking skills, reading skills and finally writing skills (Prator \& Celce-Murcia,1979). The ALM structure sequence of learning is to move from 'simple' structures (structures which offer least L1 interference) to more 'complex' structures (which offer more L1 interference) (LarsenFreeman, 1979).

\section{The Natural Approach}

The most basic facet of a communicative approach should be the presentation of comprehensible input. Krashen (1987) maintains that "comprehensible input is the true and only causative variable in L2 acquisition"(p.40). In order for an approach to be truly communicative, Krashen maintains it must focus on real communication and meaning at all times and avoid a focus based on grammatical forms. "Available evidence strongly suggests that we should not use a grammatical syllabus at all" (Krashen,1987,p.36). Krashen puts forward five hypotheses of L2 acquisition for his theoretical model - The 
Acquisition-Learning Hypothesis, The Natural Order Hypothesis, The Monitor Hypothesis, The Input Hypothesis $(i+1)$ and the Affective Filter Hypothesis. These hypotheses form the theoretical basis of the Natural Approach and contradict the behaviorist ALM beliefs that language learning is a set of 'correct' language habits (Dogget, 1986).

The first of Krashen's hypotheses, the Acquisition-Learning Hypothesis, stresses that there is a distinction between subconscious language acquisition and conscious, overt L2 learning. Acquisition reflects the true underlying grammatical forms by which a native speaker creates with his/her language.

The second of Krashen's hypotheses, the Natural Order Hypothesis, states that the acquisition of language follows a predictable order. Thus, Krashen advocates the structure of a L2 course to follow a 'natural' order rather than a grammatical one (Krashen,1987).

The Monitor Hypothesis claims that conscious learning can be used as a monitor by which to make corrections. Monitor use should be optimal according to Krashen so that L2 learners' fluency should not suffer. L2 learners should thus focus on form and grammar when they are using the target language in its written form or in formal situations, but should nevertheless not be hindered by conscious rules when engaged in oral communicative activities.

The Input Hypothesis states that a L2 learner will concentrate on meaning and not form, and will acquire new L2 structures when the current level of competence (i) is challenged by input slightly over that level $(i+1)$ (Krashen, 1987). 
Finally, the Affective Filter Hypothesis states that L2 students who have a high level of anxiety, lack of motivation or lack of self-confidence, will have a high 'affective filter' which will block input and thus hinder L2 acquisition.

The goal of the Natural Approach is the acquisition of basic communicative skills that can be used in everyday linguistic situations (Brown,1987). A second language is thus acquired in much the same way that one would acquire a first language in a 'natural' situation (Richard-Amato, 1988).

The Natural Approach holds that there are three distinct stages of L2 acquisition. In the first stage the L2 learner focuses on the development of listening comprehension skills and is characterized by a 'silent period'. The second stage is an early production stage which involves single word utterances and short phrases. The third and final stage is called the extended production stage and is characterized by longer discourse, including open-ended sentence production as well as open dialog (Krashen \& Terrell, 1983).

The Natural Approach can be used in conjunction with many other communicative methods (Richard-Amato, 1988). Indeed, the Natural Approach actually advocates the use of Asher's Total Physical Response approach (TPR) at the beginning stage of L2 acquisition. Asher based TPR on principles of child acquisition, and his approach encourages much listening and acting which would be appropriate to the Natural Approach's 'silent period' (Brown, 1987).

Natural Approach exercises focus on real communication and involve role playing, communicative problem solving, small-group exercises, skits, complex games, 
discussions, open-ended dialogs and the use of realia (Krahen \& Terrell,1983).

\section{Comparison of The ALM And The Natural Approach}

Theoretical differences between the ALM and the Natrual Approach account for their differences when employed in the classroom. An ALM oriented classroom will be teacher-centered and will rely on dialogs, pattern drills, pronunciation exercises, minimal pair drills and discrete point tests (Chamont,1985;Dogget,1986). The instructor will actively correct student errors. A classroom oriented towards the Natural Approach will be task-centered and allow for small group activities. Cognitive, sociolinguistic and discourse competence as well as interpersonal communication skills using the target language are Natural Approach goals (Chamont,1985). Such goals should also be clearly stated, relevant and explained to the students (Krashen,1987).

An ALM oriented classroom will be more structured and rigid with the L2 instructor clearly in charge of learning activities. Student errors, which are seen as 'bad habits' or failures, must be corrected. The Natural Approach, however, is more flexible and the L2 instructor is more of a facilitator of learning activities. Student errors are welcomed in a Natural Approach oriented classroom as evidence that a student is testing a hypothesis about the rules of the target language (Krashen \& Terrell,1983).

The use of repetitive drills, common to the ALM, would not be used in a Natural Approach oriented classroom as Natural Approach advocates believe that such drills would not be sufficient to foster subconcious acquisition (Krashen \& Terrell,1983).

Nevertheless, there are some similarities which would be common to ALM and Natural Approach oriented classrooms. Both the ALM and Natural Approach favor the 
introduction of reading and writing exercises after a student has mastered listening and speaking skills. Also, the ALM oriented classroom does allow for communicative conversation sessions in which L2 students are able to converse with native speakers of the target language. In this way, the L2 student in an ALM oriented classroom can indeed use communicative input in a natural situation.

\section{EXPERIMENTAL EVIDENCE}

Further experimentation is thus warranted, and therein lies the rationale behind this study. The clearest relationship between language learning theory and pedagogical approach is found in the methods of the Natural Approach (Chamont,1985), but such a clear relationship has yet to be shown empirically. In fact, experimental comparision studies have yielded somewhat inconclusive results. Krashen states that communicative approach students do outperform those students who are exposed to the ALM approach, but that the "differences are quite small" (Krashen,1987).

Some studies do indeed show data that support Krashen's statement, but this is not always the case. Samimy (1990) found no statistically significant difference between a communicative approach (Counseling-Leaming Approach) and the ALM in an experiment involving L2 students of Japanese. Savignon (1983) found in an experiment involving groups of L2 French students using 'communication' groups as well as the ALM that both the ALM and 'communication' groups scored similarly on a linguistic achievement post-test. Nevertheless, Savignon noted that the students in the 'communication' group could actually converse in French, whereas those from the ALM 
group could not.

In a two-year study labled the Pennsylvania Project, communicative based metholdology was compared with the ALM. The project was unique in that it examined student performance over a two year period. The results of tests showed no differences in student performance in any skills except reading (Chastain,1976).

In two different experiements, Nicola (1990) used L2 students of Arabic at the Defense Language Institute to compare the ALM with the Natural Approach. In both experiments the Natural Approach group outperformed the ALM group in listening and reading proficiency. The ALM group, however, outperformed the Natural Approach group in oral comprehension tests (Nicola,1990).

It is also interesting to note that in a comparison experiment conducted by Wilfried Voge (cited in Krashen,1991) in which college-level German students were grouped into those using the Natural Approach and those using a contextualized grammar approach, both groups performed equally well on discrete point grammar tests while the students exposed to the Natural Approach showed superior performance in tests of performance (i.e., speaking, writing, syntactic accuracy).

Krashen maintains that comprehensible input is the true and only causative variable in L2 acquisition and contends that studies that do not show results in which communicative experimental groups outperform ALM groups may have been flawed in that communicative groups did not receive sufficient comprehensible input (Krashen,1987). Krashen also states:

To my knowledge, comprehensible input based methods have never lost a L2 method comparason study. Comprehensible input methods have 
shown to be superior in beginning L2 acquisition with communicative tests; least effective with form based tests. (Krashen,1991,pg.417)

Krashen illustrates this point by his examination of several studies that yielded such results as well as by the discussion of an experiment by Spada (1987) in which intensive intermediate ESL students were grouped into 'grammar based' and 'meaning based' experimental groups. Results, however, showed that both groups scored similarly on a number of tests and that only on listening test sections did the 'meaning based' experimental group show a marked improvement over the 'grammar based' group.

Basic to the design of the Natural Approach is its incorporation of elements of Asher's Total Physical Response (TPR) Method. It is thus interesting to note a study (Asher,1982) in which TPR students outperformed students trained in ALM on both oral language and reading tests.

One major difference between the ALM and the Natural Approach is the use of error correction. As mentioned above, lack of error correction is a key element of the Natural Approach. Krashen maintains that comparative studies have shown that when error correction has an effect, it is minimal. Furthermore, a study by Brock, Crook, Day and Long (1985) has shown error correction to have little effect on student performance in informal situations.

Although most experimental data concerning the Natural Approach and the ALM is far from conclusive, the Natural Approach is not without its experimental successes. Ramirez and Stromquist (1979) found in a study of primary grade ESL students that a communicative approach promoted greater student growth than the ALM. Tomposky (1984) found in an experiemental comparative study of the Natural Approach and the 
ALM that the Natural Approach experimental group showed high motivation and was both interested and productive while the ALM experimental group showed low motivation and was bored and disinterested. Kessler and Quinn (1984) conducted an informal experiment with high school students using the Natural Approach which resulted in clear gains in proficiency. While the aforementioned three experiments did show gains in student performance due to Natural Approach methods, those gains were, nevertheless, based on the researchers'observations and opinions.

\section{CRITIQUE OF VALIDITY OF RESEARCH LITERATURE}

The aforementioned comparison studies have failed to catagorically support the hypothesis that a communicative approach to L2 learning results in superior quantifiable gains in student performance. Further complicating such a hypothesis is the issue of validity of the research reported in the literature. Although the direct comparison method of experimentation may seem to be straight forward and uncomplicated, it is in fact replete with difficulties and confounds (Krashen,1987).

One major difficulty of such studies stems from broad interpretations of what constitutes an approach such as the ALM or the Natural Approach. If a study were conducted and conclusions were drawn from the study's results, such conclusions would hold valid only if the experimental instructor did indeed correctly employ the respective experimental approach. In some cases experimental designs are flawed as they rely on broad, descriptive terms such as the Natural Approach or the ALM without properly defining or employing the correct methodology. In fact, Krashen (1991) goes so far as 
to counter that such study results from comparison studies could well be meaningless as it is not exactly known what is going on in experimental classrooms.

Validity of comparison studies may also be flawed if the experimental design relied on non-quantifiable or subjective criteria. Common mistakes in comparison experiments are to be found in nebulous statements such as: 'Data reported elsewhere suggest...', 'Experience shows...', 'Based on our vast experience...', and 'Evidently, it appears to lie in that...' (Hammond,1988,pg.411). It is clear that in order to obtain valid data in an experimental design, clinical data free from bias must be obtained. An interesting study illustrating such a point is found in a five-year study conducted at the University of Pittsburg (Garman,1986), in which 332 educators participated in a supervisory exercise involving observation of one English class. As the educators were unaccustomed to or unaware of the appropriate methods of clinical supervision, less than $2 \%$ of those involved could accurately account for what had transpired in the classroom. Forty three per cent of the observing educators obtained data which were only partially accurate, and $55 \%$ obtained data which were fully inaccurate. Furthermore, nuetral feelings toward the classroom teacher were exhibited by only $12 \%$ of the participants while $65 \%$ of the educators exhibited negative bias toward one classroom teacher. This study thus exemplifies the dangers of inaccurate data as well as bias in the evaluation of data in an experimental study. The fact that the rate of inaccuracy and bias was so high in this study demonstrates that the validity of a comparison study cannot be taken for granted.

Criticisms of comparison studies abound. Lozanov (1979) conducted several 
comparative studies involving his Suggestopedia Approach in which data seemed to support that Suggestopedia students consistently outperformed students using more traditional approaches such as the ALM and the Grammar-Translation Approach. Nevertheless, these experimental results may not be valid due to methodological weaknesses of the studies' design as well as the non-replicability of the studies' results (Chamot, 1985).

Certain studies yield results which on the surface would appear to support the hypothesis that the Natural Approach does indeed foster superior student gains over the ALM, but closer scrutiny of such studies could put such results in doubt. One example of such a study was conducted by Robert Mayer (1985) in an English as a Foreign Language (EFL) class in Barcelona, Spain. During a ten-week term, two groups of students participated in a comparison experiment of the the Natural Approach and the ALM. Results indicated that students from the Natural Approach group scored higher on a 'communicative' test and that Natural Approach students generally preferred the Natural Approach course design. Nevertheless, the same students who preferred the Natural Approach also suggested that they would prefer more 'traditional elements' in a language class. Furthermore, the Natural Approach experimental group of students actually scored lower on a standardized grammatical test. This would seem to put into doubt the validity of the communicative test design.

Another series of experiments in which the Natural Approach experimental group outperformed the ALM experimental group was conducted by Nicola (1990) at the Defense Language Institute. Certain limitations to this study acknowledged by Mr. 
Nicola, however, seem to invalidate this study. First of all, some teaching materials were common to both the Natural Approach and the ALM experimental groups. Also, the experiment started after the groups were already well into the course. A final experimental design flaw in this study, and perhaps the most serious, is that during the course of the experiment certain students actually left their respective experimental group for the other group (and were allowed to do so by the instructor). This alone should invalidate this study's results.

Another study which explored the efficacy of the Natural Approach was that of Berne (1990). In this study two classes were observed. One of such classes employed a traditional approach which incorporated elements of the ALM, while the other class employed the Natural Approach. The inherent problem with this study, however, was that it did not lead to an empirically based conclusion. Like the University of Pittsburg experiment, classes were observed and notes were taken. What was purportedly measured was the rapport between learners and instructors in both experimental groups, but it cannot be concluded that such results were obtained free from bias. The study did not, in my opinion, evaluate the effectiveness of either L2 learning approach and its results can thus not be accepted as valid.

Careful scrutiny of L2 methods comparative studies could lend credence to Krashen's statement that comparative studies "could well be meaningless" due to the myriad deviations from the experimental design that are indeed possible. Nevertheless, if a comparison study is well planned and properly executed, it is my opinion that such a study could very well yield results that could support or negate a L2 acquisition 
hypothesis. 
CHAPTER III

\section{RESEARCH PROCEDURES AND DESIGN}

\section{METHOD}

The method used in this thesis project was that of an experimental study. Two groups of students were involved in the experiment, and each group was exposed to four presentations. Two of these presentations delivered content material following a Natural Approach design, and the other two presentations delivered content material following an ALM design.

Experimental group A was exposed to a Natural Approach design for lessons 1 and 2, and then exposed to an ALM design for lessons 3 and 4. Experimental group B was exposed to an ALM design for lessons 1 and 2, and then was exposed to a Natural Approach design for lessons 3 and 4 . The following diagram exemplifies the experimental design:

TABLE I

METHOD OF PRESENTATION OF NATURAL APPROACH AND ALM LESSONS TO EXPERIMENTAL GROUPS

$\begin{array}{lllll}\text { LESSONS } & \underline{1} & \underline{2} & \underline{3} & \underline{4} \\ \text { GROUP A } & \text { NA } & \text { NA } & \text { ALM } & \text { ALM } \\ \text { GROUP B } & \text { ALM } & \text { ALM } & \text { NA } & \text { NA }\end{array}$




\section{SUBJECTS}

The two experimental groups of students were exposed to four experimental presentations. Two presentations for each group consisted of the delivery of content material following an ALM design, and the other two presentations consisted of the delivery of content material following a Natural Approach design. Both groups were therefore exposed to both methods and experimental group differences (if any) should be accounted for in the final statistical results.

The subjects involved in this study were first year Spanish students enrolled in my Spanish (SPN) 111 course at Oregon State University. As I am both instructor and coordinator of all first year Spanish sections, I am responsible to teach large lecture sections of the course. Each first year Spanish student must attend two lecture sections as well as two conversant sections per week. The conversant sections are relatively small (approximately 15 students each) and allow students to interact with each other and the teaching assistant using the target language. The lecture sections are large (approximately 100 students) and afford little such interaction.

The experimental content material presented to the students was presented only in the conversant sections. The students were not officially graded on such material nor was such material presented in the large lecture sections. There were 26 conversant sections during the fall quarter of 1992 , and half of these sections made up Group A and half made up Group B. It is also noteworthy that students were assigned conversant sections by computer and thus were not able to actively choose to be part of either Group A or Group B. Also, the students were not premitted to switch groups during the 
experiment and were required to attend the conversant section in which they were enrolled.

In addition to having similar, randomly chosen experimental groups, the students were not informed that they were participating in an experiment in either experimental group in order to avoid the 'Hawthorne effect' of student expectations. If the students are unaware that they are part of an experimental group following a certain L2 instructional approach, they will not feel a need to act upon any expectations which the instrutor may have. They should thus perform in a normal, natural way.

The overall number of subjects was dependent upon class enrollments, and at the end of the experiment the number of subjects was tabulated at 249. Group A was comprised of 125 subjects and Group B was comprised of 124 subjects. Each experimental group consisted of 13 conversant sections.

\section{PROCEDURES}

All students from groups A and B received all four lessons, but Group A received lessons 1 and 2 following a Natural Approach design, while Group B received lessons 1 and 2 following an ALM design. Group A then received lessons 3 and 4 following an ALM design while Group B received lessons 3 and 4 following a Natural Approach design. Seven teaching assistants were assigned to present the lessons and each teaching assistant presented experimental material to only one specific experimental group. As teaching assistants administered all experimental lessons, it was important that each teaching assistant be exposed to only one experimental lesson plan for each of the four 
lessons. Teaching assistants followed lesson plans which were written out and modelled for them according to their corresponding experimental group. Therefore, each teaching assistant was responsible for either a Natural Approach or an ALM lesson and could not 'mix up' lesson plans and approaches. To have done so would have invalidated the entire study.

Each experimental lesson thus had two different lesson plans: one which followed ALM guidelines and one which followed Natural Approach guidelines. Both lesson plans covered identical content material insofar as the presentation of new vocabulary and grammatical and structural language concepts. Each lesson was topical in that it dealt with a certain subject (i.e., food, the home, the city and health).

Lesson plans were designed carefully so as to follow as closely as possible the true Natural Approach or ALM design. The Natural Approach - Language Acquisition the Classroom by Krashen and Terrell (1983) was used as a main reference for Natural Approach exercises. Certain exercises were taken directly from this text and other exercises were developed using the text's Natural Approach guidelines (Appendix A).

ALM lesson plans (Appendix B) were developed following guidelines such as those listed by Celce-Murcia (1979). In addition, I am also personally quite familiar with the ALM lesson design due to my student teaching experience at Princeton High School in 1982, where I taught Spanish for one academic semester and was expected to use an ALM approach in the classroom. Also, the text which is currently used for our first year Spanish program at Oregon State University, Hablamos Español, is based on the ALM. The first lesson, The House (La Casa), was presented to the students in their 
conversant classes on October 26-27, 1992. The Natural Approach lesson plan included a 'guided tour' in Spanish of a floor plan of a house which was shown on an overhead projector. Students were silent during this exercise. Later, simple yes/no questions were asked of students, followed by simple sentence responses. Then, students got into pairs and one student had to explain his/her house to the other student as that student drew a simple houseplan on paper. Papers were not collected. The final Natural Approach exercise involved a role-play between two students in which one student portrayed a real estate agent and one a prospective buyer. The 'agent' had to find out what the buyer wanted in a house and the buyer had to answer questions and make his/her wishes known. There was no overt error correction during this Natural Approach lesson and students were told ahead of time what each exercise entailed as well as its goal.

The ALM lesson for The House started with a taped dialog. For each ALM lesson I wrote and taped a dialog which contained the necessary new vocabulary and grammatical and structural concepts of the lesson. The dialogs were always between 'Jose Luis' (myself) and 'Carmen' (Teaching Assistant \#1). These original dialogs were loosely based on the situational dialogs between 'Jose Luis' and 'Carmen' in the Hablamos Español text. In the dialog from this lesson, 'Carmen' shows 'Jose Luis' around her house. Students listened to the dialog three times and then were involved in a repetition exercise in which they had to repeat small parts of the dialog as modeled by the instructor. Students then were exposed to several repetition and cloze exercises which were all conducted orally. Pronunciation as well as grammatical errors were overtly corrected. 
The second lesson was entitled La Comida (food) and was conducted on November 2-3, 1992. The Natural Approach lesson began with instructors taking out plastic fruits and vegetables and soup cans and identifying each one in Spanish. The instructor then handed an item to a student so that each student was holding one item. Then, when the instructor called the name of a certain food, the student who held the food item had to stand. The instructor continued to do so randomly until all students had stood up several times. Then, the students exchanged food items several time. Next, the instructor passed out menus in Spanish of 'La Pampa' Restaurant to each student. The instructor went over each food item on the menu and showed a picture of each food item not seen in the previous exercise. Following was a role-play using the menus in which one student portrayed a waiter while the other student portrayed the restaurant patron. The role-play was done in pairs and was done several times with different partners.

The ALM lesson for the La Comida lesson began with a taped dialog of 'Jose Luis' and 'Carmen' in a restaurant where the food was not very good. ('Jose Luis' and 'Carmen' discussed the same foods which were presented in the Natural Approach lesson plan.) After listening to the tape, students participated in a repetition exercise in which their pronunciation errors were overtly corrected. The students then participated in verb conjugating exercises which also involved substantial repetition. Following were several exercises in which students had to complete a sentence with a food item after being prompted by the instructor.

The third lesson was conducted on November 16-17, 1992, and was entitled The 
City. The Natural Approach lesson began with an overhead map of the downtown section of San Jose, Costa Rica. On the map there were several places and buildings identified in Spanish. Also identified were the corresponding street and avenue names. The instructor then pointed to each place on the map and described each place in Spanish while using a prop or realia in order to give students a concrete visual aid. (For example, The Pharmacy, the instructor held up some empty medicine vials from the Health Center; The Post Office - the instructor held up an air mail envelope; The Bank the instructor held up some Costa Rican 5 and 10 Colon notes; etc..) Next, the instructor proceeded to identify where each place was located while identifying the corresponding place on the overhead map. Students were then asked to answer simple questions and identify places. The final exercise involved students grouped into pairs. One student received 'Map A' and the other student received 'Map B'. Each student also received a list of questions regarding destinations on a sheet of paper. Students then had to 'find' places and arrive at destinations by asking each other questions based on Maps A and B. (The aforementioned lesson plan was taken from The Natural Approach (Krashen \& Terrell, 1983).

The ALM oriented lesson began with a taped dialog of 'Jose Luis' and 'Carmen', who also find themselves in the center business district of San Jose, Costa Rica. Students listened to the dialog three times and then participated in a repetition exercise involving small parts of the dialog. Pronunciation errors were overtly corrected. Students then participated in an exercise where they read parts of the dialog in small groups. Following were five different exercises in which the students were exposed to 
structures which were sequenced and presented in an increasing order of complexity.

The fourth lesson was conducted on November 18-19, 1992, and was entitled Health. The Natural Approach lesson began with the instructor introducing certain body parts by pointing to him/herself and slowly pronouncing the corresponding word in Spanish. Following was a TPR exercise in which students had to point to themselves indicating a corresponding body part. Next, the instructor had to play act that a part of his/her body hurt in order to model the correct forms of the Spanish verb 'doler' (to hurt). Students were then asked yes/no questions regarding the instructor's feigned malaise. Finally, the class was divided into groups of 'doctors' and 'patients'. The 'patients' had to come in to see a 'doctor' with a litany of complaints in Spanish and respond to the 'doctor's' questions. Pairs of students were interchanged several times and students were required to play both the roles of 'doctor' and 'patient'.

The ALM oriented lesson plan for the lesson entitled Health began with a trip by 'Jose Luis' and 'Carmen' to the doctor's office. After listening to the dialog three times, the students participated in a repetition exercise. Students then got into groups of two and read the dialog aloud, with each student reading the part of either 'Jose Luis', 'Carmen' or the doctor. Following were four different sequenced exercises which stressed repetition, substitution, pattern drills and verb conjugation exercises.

The teaching assistants administered the aforementioned experimental lessons after attending training sessions in which I explained and modelled the corresponding lessons to them. The normal procedure for the SPN 111 course training sessions involves a meeting each Friday in which I explain and model the conversant lesson plans to the 
teaching assistants for the upcoming academic week. During the experiment, however, it was necessary to schedule two separate training sessions: one for Group A instructors and one for Group B instructors. I felt it important that Group A instructors that present Natural Approach lesson plans should not be familiar with the ALM lesson plans and vice-versa. Also, the lesson plans for both Group A and Group B instructors were carefully written out for them and they were made to understand that they were expected to meticulously follow the lesson plan. As a further added safeguard, they were informed that an 'observer' would discreetly monitor their classes in order to acertain that the appropriate lessons were indeed being administered. All teaching assistants agreed to such conditions and freely signed informed consent forms (Appendix C).

The lesson plans were then carried out by the instructors, and according to the discreet 'observer', the instructors properly presented the lessons following the appropriate lesson plan. The observer attended the first given class of each teaching assistant for lessons 1 through 4 . She sat unobtrusively in the class and made no attempt to participate in the lesson nor correct the teaching assistant. As the teaching assistant presented the lesson, the observer followed along with a printed copy of the lesson plan in order to ascertain if the teaching assistant did indeed follow the plan accordingly. The observer was not, however, trained in the methods of the Natural Approach nor the ALM as it was solely incumbent upon her to notify me immediately if a teaching assistant did not follow a specific lesson plan. All teaching assistants involved did follow the corresponding lesson plans (they were informed and aware that an observer would be monitoring them). It is noteworthy, however, that the observer did not monitor all 
lesson presentations, but only the first presentation of each lesson. I assumed that if the teaching assistants presented the lesson properly the first time, they would continue to present that certain lesson properly in the absence of an observer.

\section{INSTRUMENTATION}

Testing in this study was replicable and was made to conform to certain safeguards in order to protect the overall validity of the study. All students were pretested for experimental content material prior to the presentation of any such material. Pre-tests were administered in the large lecture class and all subjects received identical written pre-tests (Appendices D,E,F,G,H,I).

A day or two after the presentation of the content material was made to both Group A and Group B, an identical test was administered to all subjects in the large lecture class. Two different tests were administered: Test 1 , which covered content material from lessons 1 and 2, and Test 2, which covered content material from lessons 3 and 4 . These tests were designed to measure short-term acquisition of the content material.

Several weeks after the tests were administered, post-tests were administered to all subjects. The post-test scores should aid in making generalizations regarding students' longer term retention using both the ALM and the Natural Approach.

Originally I had planned to administer longer tests with a varied number and style of test questions. However, it was made clear to me by OSU administrators that such tests could not take up a lot of class time. It was therefore necessary to construct shorter 
tests which could accurately measure students' acquisition of the content material. I chose a pragmatic design of language test which required the students to utilize normal contextual constraints on sequences in the language as well as use sequences in relation to extralinguistic contexts (Coller, 1979). Each pre-test, test and post-test was set up in an identical format but required the student to elicit different responses (i.e., different verb conjugations, different vocabulary items, different demonstrative adjectives, etc.). This was done in order to insure that the level of difficulty of each test was constant. Correct responses to the questions were quantifiable and were taken directly from each experimental lesson in order to protect the tests' content validity. Examples of test questions are as follows:

- How would you do the following in Spanish?

1. Order a drink.

2. Ask for dessert.

3. Ask for a menu.

- Suppose you were in a city in Costa Rica. How would you ask someone in Spanish the location of the following: the bus stops, the banks, the repair shop, the bakery and the clothing store? (EXAMPLE: Where is the ?)

- Imagine that you are showing a Spanish speaking friend around your house. You will thus write in Spanish: This is the (room or item) or These are the (rooms or items) for the following: the couch, the kitchen, the coffee tables and the bedrooms. Please use complete sentences! 
- How would you tell a doctor in Spanish you were suffering from the following: a sore arm, sore feet, sore fingers, a headache and a backache? (EXAMPLE: My arm, feet, fingers, etc. hurts.)

- _ _ usted el menu o yo? Que tu y que ? Ellos _ mucho pero nosotros no nada. (This is a cloze exercise of the conjugation of the verb 'pedir')

Identical keys for all tests were written and strictly adhered to during the correction of the tests. Also, all tests were graded by the same person as a safeguard for inter-rater reliablility. 


\section{CHAPTER IV}

\section{RESULTS}

The purpose of this study was to examine the short term and long term retention of content material by L2 students exposed to both the ALM and the Natural Approach. Students were randomly split into two groups which were exposed to two different Natural Approach and ALM design lesson plans. The experiment was thus set up in a cross-over design in which Group A was exposed to lessons 1 and 2 using Natural Approach lesson plans while Group B was exposed to lessons 1 and 2 using ALM lesson plan design. Group A was then exposed to ALM design lesson plans for lessons 3 and 4 while Group B was exposed to Natural Approach lesson plans for the same lessons.

\section{DEPENDENT VARIABLES}

The dependent variables in this study were the students' pre-test, test and post-test scores. Short term retention was calculated by subtracting the mean pre-test score from the mean test score. Long term retention was calculated by subtracting the mean pre-test score from the mean post-test score.

\section{INDEPENDENT VARIABLES}

The independent variables in this study consisted of method and teaching assistant.

The independent variables were thus used as the treatment factors in the statistical 
analysis.

\section{STATISTICAL ANALYSIS}

The statistical tool chosen for analyzing the data was that of the Two-Way Analysis of Variance (ANOVA) given that more than two means were compared and that the data were scores of an independent, between-group design which were distributed so that mean was the measure of central tendency (Hatch \& Lazarton, 1991).

The ANOVA utilizes the $F$ ratio and hypotheses can be rejected when the $F$ value equals or exceeds the tabulated $\mathrm{F}$ value at the designated alpha level. The alpha level used to denote significance in this study was established at probability $(p)<.05$.

\section{Research Question 1}

Are short term L2 gains of students exposed to a Natural Approach lesson design superior to the short term L2 gains of those students exposed to an ALM lesson design?

\section{Hypothesis 1}

Students who are exposed to L2 content material using a Natural Approach lesson design will outperform those students who are exposed to the same content material using an ALM lesson design in quantifiable test score gains.

The following tables show the pre-test and test scores for both the Natural Approach and the ALM teaching methods. All tests were graded on a percentage scale with each test having a range of $0 \%$ to $100 \%$. 
TABLE II

PRE-TEST AND TEST MEAN SCORES AND STANDARD DEVIATIONS USING THE NATURAL APPROACH TEACHING METHOD

\begin{tabular}{llcc}
\hline & Number & Mean & Standard Deviation \\
\hline Pre-test Score & 446 & 12.15 & 16.3 \\
Test Score & 420 & 24.73 & 21.9 \\
\hline
\end{tabular}

TABLE III

PRE-TEST AND TEST MEAN SCORES AND STANDARD DEVIATIONS USING THE ALM TEACHING METHOD

\begin{tabular}{llcc}
\hline & Number & Mean & Standard Deviation \\
\hline & 443 & 13.28 & 16.2 \\
Pre-test Score & 427 & 26.92 & 23.1 \\
Test Score & & & \\
\hline
\end{tabular}

Analysis of variance measures produced statistically nonsignificant group differences for the teaching method employed $(p=0.59)$. Based on the analysis of variance between method results, Hypothesis 1 was rejected.

ANOVA measures for the teaching assistant variable were also found to be nonsignificant $(p=.07)$. Although teaching assistants are a nominal variable, they were assigned numbers (\#1-\#7) in order to ensure confidentiality and also to enable a statistical ananysis of the teaching assistant variable. Assistants from the Oregon State University Department of Statistics recommended the use of teaching assistant as an independent 
variable as this is customary in a cross-over research design study using more than one teaching assistant. The rationale behind the measurement of this independent variable lies in that if one teaching assistant is biased toward one teaching method, his/her presentation of such lesson could be unequal and could conceivably lead to biased results. It was therefore important to separate the effects of the teaching assistant from the effects of the teaching method employed in order to insure that results were not biased by a teaching assistant. The following table shows pre-test and test mean scores for teaching assistants for both the Natural Approach and ALM experimental lessons.

\section{TABLE IV}

TEACHING ASSISTANTS: COMPARISON OF PRE-TEST AND TEST MEAN SCORES

\begin{tabular}{|c|c|c|}
\hline Teaching Assistant & Natural Approach Lessons & ALM Lessons \\
\hline$\# 1$ & $\begin{aligned} \text { Pre-test mean } & =7.0 \\
\text { Test mean } & =22.2 \\
\text { number }(n) & =79\end{aligned}$ & $\begin{array}{c}\text { Pre-test mean }=21.0 \\
\text { Test mean }=38.6 \\
n=84\end{array}$ \\
\hline$\# 2$ & $\begin{array}{c}\text { Pre-test mean }=7.7 \\
\text { Test mean }=20.0 \\
n=38\end{array}$ & $\begin{array}{c}\text { Pre-test mean }=13.8 \\
\text { Test mean }=33.9 \\
n=40\end{array}$ \\
\hline \#3 & $\begin{array}{c}\text { Pre-test mean }=7.5 \\
\text { Test mean }=17.3 \\
\mathrm{n}=26\end{array}$ & $\begin{array}{c}\text { Pre-test mean }=12.7 \\
\text { Test mean }=36.8 \\
\mathrm{n}=28\end{array}$ \\
\hline$\# 4$ & $\begin{array}{c}\text { Pre-test mean }=9.1 \\
\text { Test mean }=17.6 \\
n=65\end{array}$ & $\begin{array}{c}\text { Pre-test mean }=15.0 \\
\text { Test mean }=29.6 \\
\mathrm{n}=75\end{array}$ \\
\hline
\end{tabular}


TABLE IV

TEACHING ASSISTANTS: COMPARASON OF PRE-TEST AND TEST MEAN SCORES

(continued)

\begin{tabular}{|c|c|c|}
\hline Teaching Assistant & Natural Approach Lessons & ALM Lessons \\
\hline$\# 5$ & $\begin{array}{c}\text { Pre-test mean }=20.5 \\
\text { Test mean }=31.1 \\
\mathrm{n}=56\end{array}$ & $\begin{array}{c}\text { Pre-test mean }=10.1 \\
\text { Test mean }=21.9 \\
n=52\end{array}$ \\
\hline$\# 6$ & $\begin{array}{c}\text { Pre-test mean }=13.8 \\
\text { Test mean }=27.6 \\
\mathrm{n}=92\end{array}$ & $\begin{array}{c}\text { Pre-test mean }=9.6 \\
\text { Test mean }=16.1 \\
n=92\end{array}$ \\
\hline$\# 7$ & $\begin{array}{c}\text { Pre-test mean }=14.9 \\
\text { Test mean }=30.9 \\
n=64\end{array}$ & $\begin{array}{c}\text { Pre-test mean }=7.5 \\
\text { Test mean }=18.2 \\
\mathrm{n}=59\end{array}$ \\
\hline
\end{tabular}

As this study was of a cross-over research design, Group A received lessons 1 and 2 following a Natural approach lesson design and then received lessons 3 and 4 following an ALM lesson design. Group B, on the other hand, received lessons 1 and 2 following an ALM design and received lessons 3 and 4 following a Natural Approach design. Assistants from the Oregon State University Department of Statistics recommended that in addition to conducting ANOVA measures between Group A and Group B for teaching method, it would be necessary to conduct ANOVA measures for the effects of teaching method within each experimental group. The effects of teaching method were thus measured within each experimental group and the differences between the two teaching methods were found to be significant for both Group A and Group B. 
This finding was important to address as it could have meant that the experimental groups were not as equal as random selection would assume. Therefore, experimental lesson was treated as an independent variable and there was found to be signficant $(P=.0026)$. Further results were thus compiled to investigate this phenomenon based on mean scores taken individually from lessons 1 through 4 .

TABLE V

COMPARISON OF MEAN SCORES AND STANDARD DEVIATIONS FOR PRE-TEST AND TEST FOR LESSONS 1 THROUGH 4 WITHIN GROUP A

\begin{tabular}{lcclc}
\hline Lesson & Pre-test mean & SD & Test mean & SD \\
\hline Lesson 1 & 17.3 & 15.1 & 34.1 & \\
Lesson 2 & 14.4 & 19.0 & 29.9 & 21.5 \\
Lesson 3 & 13.9 & 16.6 & 24.0 & 22.9 \\
Lesson 4 & 4.3 & 10.5 & 11.6 & 18.6 \\
\hline
\end{tabular}

TABLE VI

COMPARISONS OF MEAN SCORES AND STANDARD DEVIATIONS FOR PRE-TEST AND TEST FOR LESSONS 1 THROUGH 4 WITHIN GROUP B

\begin{tabular}{lcclc}
\hline Lesson & Pre-test mean & SD & Test mean & SD \\
\hline Lesson 1 & 19.3 & 15.4 & 37.0 & 21.0 \\
Lesson 2 & 14.3 & 17.6 & 32.0 & 25.8 \\
Lesson 3 & 13.2 & 17.1 & 23.4 & 18.7 \\
Lesson 4 & 2.6 & 6.8 & 13.2 & 19.4 \\
\hline
\end{tabular}

Results of the means in Tables IV and $\mathrm{V}$ indicate that the mean difference 
between test and pre-test was greater for both groups A and B for lessons 1 and 2 than for lessons 3 and 4. This would indicate that all students, regardless of group or method, showed more quantifiable gains for the first two lessons than for the last two lessons. Within Group A there was a difference between method as lessons 1 and 2 (Natural Approach lesson plan designs) showed greater quantifiable gains (Lesson $1=+16.8$; Lesson $2=+15.5$ ) than lessons 3 and 4 (Lesson $3=+10.1$; Lesson $4=+7.3$ ) (ALM lesson plan designs). Within Group B a similar phenomenon occured as lessons 1 and 2 (ALM lesson plan designs) showed greater quantifiable gains (Lesson $1=+17.3$; Lesson $2=+18.0$ ) than lessons 3 and 4 (Lesson $3=+9.8 ;$ Lesson $4=+10.8$ ) (Natural Approach lesson plan designs). It is noteworthy that in comparison of method within each individual lesson there was not one significant score (Lesson 1: $p=.66$; Lesson 2: $\mathrm{p}=.09$; Lesson $3: \mathrm{p}=.60$; Lesson $4: \mathrm{p}=.61$ ). Within-group method effects thus are probably attributable to lesson and not to method.

Hypothesis 1 was therefore rejected as method was not found to be significant.

\section{Research Question 2}

Are long term L2 gains of students exposed to a Natural Approach design superior to the long term L2 gains of those students exposed to an ALM lesson design?

\section{Hypothesis 2}

Students who are exposed to L2 content material using a NA lesson design will outperform those students who are exposed to the same content material using an ALM lesson design in quantifiable test score gains. 
The following tables show the pre-test and post-test scores for both the Natural Approach and ALM teaching methods.

TABLE VII

PRE-TEST AND POST-TEST MEAN SCORES AND STANDARD DEVIATIONS

USING THE NATURAL APPROACH TEACHING METHOD

Number

446

479
Mean

12.1

31.6
Standard Deviation

16.3

TABLE VIII

PRE-TEST AND POST-TEST MEAN SCORES AND STANDARD DEVIATIONS USING THE ALM TEACHING METHOD

Number Mean Standard Deviation

Pre-test Score

443

13.2

16.2

Post-test Score

485

31.3

24.7

Analysis of variance measures produced statistically nonsignificant group differences for the teaching method employed $(p=.09)$. Based on the analysis of variance between method results, Hypothesis 2 also was rejected.

ANOVA measures for the teaching assistant variable were also found to be nonsignificant $(p=.11)$. Table IX shows pre-test and post-test mean scores for teaching assistants for both the Natural Approach and ALM experimental lessons. 
TABLE IX

TEACHING ASSISTANTS: COMPARISON OF PRE-TEST AND POST-TEST MEAN SCORES

\begin{tabular}{|c|c|c|}
\hline Teaching Assistant & Natural Approach Lessons & ALM Lessons \\
\hline$\# 1$ & $\begin{array}{l}\text { Pre-test mean }=7.0 \\
\text { Post-test mean }=22.1 \\
\text { number }(n)=79\end{array}$ & $\begin{array}{c}\text { Pre-test mean }=21.0 \\
\text { Post-test mean }=43.2 \\
n=84\end{array}$ \\
\hline$\# 2$ & $\begin{array}{c}\text { Pre-test mean }=7.7 \\
\text { Post-test mean }=21.7 \\
n=38\end{array}$ & $\begin{array}{c}\text { Pre-test mean }=13.8 \\
\text { Post-test mean }=43.2 \\
n=40\end{array}$ \\
\hline$\# 3$ & $\begin{array}{c}\text { Pre-test mean }=7.5 \\
\text { Post-test mean }=18.4 \\
n=26\end{array}$ & $\begin{array}{c}\text { Pre-test mean }=12.7 \\
\text { Post-test mean }=37.3 \\
n=28\end{array}$ \\
\hline$\# 4$ & $\begin{array}{c}\text { Pre-test mean }=9.1 \\
\text { Post-test mean }=18.6 \\
n=73\end{array}$ & $\begin{array}{c}\text { Pre-test mean }=15.0 \\
\text { Post-test mean }=38.3 \\
n=77\end{array}$ \\
\hline \#5 & $\begin{array}{c}\text { Pre-test mean }=20.5 \\
\text { Post-test mean }=42.3 \\
n=56\end{array}$ & $\begin{array}{c}\text { Pre-test mean }=10.1 \\
\text { Post-test mean }=21.3 \\
\qquad n=51\end{array}$ \\
\hline \#6 & $\begin{array}{c}\text { Pre-test mean }=13.8 \\
\text { Post-test mean }=40.9 \\
n=92\end{array}$ & $\begin{array}{c}\text { Pre-test mean }=9.6 \\
\text { Post-test mean }=18.0 \\
n=91\end{array}$ \\
\hline$\# 7$ & $\begin{array}{c}\text { Pre-test mean }=14.9 \\
\text { Post-test mean }=45.0 \\
\qquad n=64\end{array}$ & $\begin{array}{c}\text { Pre-test mean }=7.5 \\
\text { Post-test mean }=24.3 \\
n=59\end{array}$ \\
\hline
\end{tabular}

The effects of teaching method were thus measured within each experimental group and the differences were found to be significant for both Group A and Group B. 
This finding was important to address as it could have meant that the experimental groups were not as equal as random selection would assume. Lesson was treated as an independent variable and there was found to be a significant difference $(p=.0001)$. Further results were thus compiled to investigate this phenomenon based on mean scores taken individually from lesson 1 through 4.

TABLE X

COMPARISON OF MEAN SCORES AND STANDARD DEVIATIONS FOR PRE-TEST AND POST-TEST FOR LESSONS 1 AND THROUGH 4 WITHIN GROUP A

\begin{tabular}{lcclc}
\hline Lesson & Pre-test mean & SD & Post-test mean & SD \\
\hline Lesson 1 & 17.3 & 15.1 & 46.4 & \\
Lesson 2 & 14.4 & 19.0 & 38.5 & 18.1 \\
Lesson 3 & 13.9 & 16.6 & 23.9 & 25.2 \\
Lesson 4 & 4.3 & 10.5 & 14.4 & 21.3 \\
& & & & \\
\hline
\end{tabular}

TABLE XI

COMPARISON OF MEAN SCORES AND STANDARD DEVIATIONS FOR PRE-TEST AND POST-TEST FOR LESSONS 1 THOROUGH 4 WITHIN GROUP B

\begin{tabular}{lcccc}
\hline Lesson & Pre-test mean & SD & Post-test mean & SD \\
\hline Lesson 1 & 19.3 & 15.4 & 46.6 & \\
Lesson 2 & 14.3 & 17.6 & 36.9 & 17.0 \\
Lesson 3 & 13.2 & 17.1 & 25.0 & 26.3 \\
Lesson 4 & 2.6 & 6.8 & 14.0 & 20.3 \\
\end{tabular}


Results of the means in Tables IX and $\mathrm{X}$ indicate that the mean difference between pre-test and post-test was greater for both groups A and B for lessons 1 and 2 than for lessons 3 and 4. This would indicate that all students, regardless of group or method, showed more quantifiable gains for the first two lessons than the last two lessons. So, within Group A there was a difference between method as lessons 1 and 2 (Natural Approach lesson plan designs) showed greater quanitifiable gains (Lesson 1 $=+29.1 ;$ Lesson $2=+24.1$ ) than lessons 3 and 4 (Lesson $3=+10.0 ;$ Lesson $4=+8.1$ ) (ALM lesson plan designs). Within Group B a similar phenomenon occurred as lessons 1 and 2 (ALM lesson plan designs) showed greater quantifiable gains (Lesson 1 $=+27.3 ;$ Lesson $2=+22.6)$ than lessons 3 and 4 (Lesson $3=+11.8 ;$ Lesson $=+11.4$ ) (Natural Approach lesson plan designs). It is noteworthy that in comparison of method within each individual lesson there was not one significant score (Lesson 1: $p=.54$; Lesson 2: $p=.93$; Lesson $3: p=.61$; Lesson $4: p=.47$ ). Within-group method effects thus are probably attributable to lesson and not to method.

Hypothesis 2 was therefore rejected as method was not found to be significant. 


\section{CHAPTER V}

\section{DISCUSSION}

\section{SUMMARY OF RESEARCH}

The purpose of this study was to determine the difference in the short term and long term L2 gains of first year Spanish students exposed to the ALM and the Natural Approach. The experiment consisted of two randomly selected groups which were exposed to four presentations. Two of such presentations delivered content material following a Natural Approach lesson design while the other two delivered content material following an ALM lesson design in such a way that both groups were exposed to two ALM lessons. All subjects were pre-tested prior to the delivery of said lessons and subsequently tested after the first lessons for short term L2 gains. The number of subjects that participated in the experiment was 249 and included all enrolled first year Spanish students at Oregon State University for the 1992 fall term.

The data were analyzed using the two-way analysis of variance. The alpha level used to denote significance in this study was established at $(\mathrm{p})<.05$.

\section{DISCUSSION OF THE RESEARCH RESULTS}

Two hypotheses were proposed. The first hypothesis held that students exposed to L2 content material using a Natural Approach lesson design would outperform those 
students who were exposed to the same content material using an ALM lesson design in quantifiable test score gains. ANOVA measures produced statistically nonsignificant group differences for teaching method employed. All the data for both groups were examined as well as when each individual lesson was measured. Hypothesis 1 was therefore rejected based on the ANOVA results.

The second hypothesis held that students exposed to L2 content material using a Natural Approach lesson design would outperform those students who were exposed to the same content material using an ALM lesson design in quantifiable test score gains. Again, ANOVA measures produced statistically nonsignificant group differences for teaching method employed when all the data for both groups were examined as well as when each individual lesson was measured. Hypothesis 2 was therefore rejected based on the ANOVA results.

The rejection of the research hypotheses is consistent with the results of many previous experiments in which the ALM was compared with a communicative L2 approach (Krashen \& Terrell,1983; Nicola,1990; Saminy, 1990; Savignon, 1983).

Nevertheless, one factor which must be considered when examining such results is that of the length of exposure to the content material. In this research experiment the students were exposed to four different experimental lessons based on content material from two different lesson design approaches. Applicable questions could conceivably be raised regarding the duration of the experimental lessons. Would teaching method have been a statistically significant factor if there had been more long term exposure to the Natural Approach lesson plans? If an entire academic quarter had been devoted to each 
teaching method would the outcome have been different? These questions could be answered if this study had taken place over a longer period of time and had exposed the experimental groups to additional experimental Natural Approach and ALM lessons.

The experimental results indicate, however, that teaching method was not statistically significant on either short term or long term L2 language gains. Further analysis of data was done in order to substantiate such results. The first question which arose was that of the teaching assistants' delivery of the relevant content material. Eventhough there was an 'observer' to monitor the teaching assistants' delivery of the appropriate lesson plan, it was conceivable that teaching assistant as an independent variable could have an effect on results. A teaching assistant could harbor a personal bias toward one of the teaching methods and thus could present certain lesson plans more enthusiastically than others. Students' attitudes as well as test scores could be affected given such circumstances. Also, the teaching assistants were observed only during the first of all four Natural Approach and ALM lessons. It was assumed that if the teaching assistants successfully presented the first Natural Approach and ALM lessons that they would repeat such lessons in an appropriate manner. Therefore, given the aforementioned uncertainties, ANOVA measures for teaching assistant were conducted and were found to be statistically nonsignificant. This is important as it would indicate that the differences in teaching method were not dependent on the teaching assistants' presentation of the content material. Students' mean score variance was not statistically different due to the students' respective teaching assistant.

Another factor which could have been significant to the study was that of a 
within-group effect. As this study was of a cross-over research design, Group A received lessons 1 and 2 following a Natural Approach design and then received lessons 3 and 4 following and ALM design. Group B, on the other hand, received lessons 1 and 2 following an ALM design and received lessons 3 and 4 following a Natural Approach design. For both hypothesis 1 and 2 there was a statistically significant effect of teaching method (within group) for both Groups A and B. Nevertheless, further investigation of the data showed that both groups' test score data showed greater mean variance for lessons 1 and 2 than for lessons 3 and 4, regardless of group. All subjects thus showed greater quantifiable L2 gains on the first two lessons, regardless of teaching method. A possible explanation for this phenomenon is that the first two lessons deait with content material more easily acquired than the last two lessons. The first lessons dealt with the verb 'pedir', demonstratives and vocabulary items, while the last two lessons dealt with 'estar', 'doler' and other vocabulary items. The difference in test scores could possibly have been due to the irregularities of the verbs 'estar' and 'doler', which are somewhat more complex than the verb 'pedir'. The vocabulary presented in all lessons is concrete, useful and simplistic. Thus, it is unlikely that test score differences would be due to the vocabulary items presented. The manner in which this content material was presented (i.e., teaching method) does not appear to be a factor.

It is interesting to note the large standard deviations of pre-test, test and post-test score results. Such large standard deviations indicate that there were many low scores as well as high scores. This could be attributable to the different levels of student achievement and motivation in the Spanish 111 class. Enrolled in the class were not only 
freshmen and sophomores, but also many upper-division and graduate students. It is possible that upper-division and graduate students scored higher on tests given their experience and motivation in the higher education system. Also, there is a high rate of failure in the Spanish 111 course, especially among incoming freshmen students. Furthermore, it is also possible that as students were aware that the tests would not count toward their final grade, some students may not have taken the tests seriously and consequently received very low scores. Thus, student motivation as well as ability could have both accounted for the large range of test scores.

\section{Observations}

Based on the results of this study, it is thus not possible to state that the Natural Approach is superior to the ALM in terms of quantifiable student gains. Likewise, it would not be possible to state that the ALM is a superior approach in terms of quantifiable student gains based on the results of this study. Both teaching methods had a significant effect in student performance on quanitifiable L2 gains as measured by a significant difference between pre-test and test scores as well as between pre-test and post-test scores.

It would, however, be valuable to address other questions of a non-quantifiable nature based on observations from this experimental study. For example, were student reactions generally more favorable to L2 lessons following the Natural Approach guidelines? Which of the two types of L2 learning approaches do the instructors favor? Which of the types of L2 learning approaches do the instructors find easier to use? And finally, is the training of instructors in the methods of the Natural Approach easier than 
that of the ALM and how responsive are the instructors to being trained in each of those approaches?

The first observation regarding the Natural Approach and ALM lesson plans, which could be attributable in part to my previous experience with the ALM, is that I found the Natural Approach lesson plans to be more time consuming to write and more difficult to develop. Also, extra time and effort was required in that certain realia and other materials used with the Natural Approach had to be either obtained or created. The ALM orented lesson plans, on the other hand were much easier to design and write, perhaps due to the lessons' similar design.

My observations from the teaching assistant training sessions were that the Natural Approach lesson plans took longer to explain and model and were less easily understood. It was necessary to repeat Natural Approach exercises and explanations several times before teaching assistants clearly understood how to correctly present the lesson. I estimated that Natural Approach lesson plan training sessions lasted two to three times longer than the ALM lesson plan training sessions. (I did not end a session until I felt confident that the teaching assistants were thoroughly prepared to present the appropriate lesson properly.) Nevertheless, although I found the ALM lesson plans much easier and quicker to model and explain, I noticed that several teaching assistants seemed somewhat bored during these training sessions. Although the Natural Approach training sessions were more difficult for the teaching assistants, the Natural Approach sessions did generate more enthusiasm.

After the experimental lessons were presented I asked the instructors their 
opinions regarding the lessons as well as how they perceived students' reactions. The instructors clearly preferred the Natural Approach lessons (although one instructor said he did like the ALM taped dialogs). The following are some student reactions to the ALM lesson plans as told to me by the teaching assistants:

-"They hated it."

-"People were bored."

-"Due to many student complaints one teaching assistant considered the ALM section a failed experiment."

-"Several people came to the class with a lot of energy and then later fell asleep."

-"They were not thinking; they were on 'automatic'."

-"The students achieved better pronunciation with the ALM." (Several teaching assistants made a similar comment.)

The following are some student reactions, as told to me by the teaching assistants, to the Natural Approach lesson plans:

-"Students especially liked the plastic fruit exercise from the Food lesson."

-"Students liked being in groups." (Several teaching assistants made a similar comment.)

-"The Natural Approach lesson made it harder to control students."

-"Some students did not like the exercise in which they had to draw a house plan."

Student reactions were generally more favorable toward the Natural Approach lessons, and the aforementioned observations are consistent with obervations made in previous experimental studies in which the ALM was compared with a communicative approach (Bern,1990; Mayer,1985; Nicola,1990). 
It is probable that there is no significant difference in the effectiveness of either the ALM or the Natural Approach in terms of short term or long term quantifiable student gains. Nevertheless, based on observations made in this study, it is my opinion that the Natural Approach has many qualities which are popular with students as well as with instructors.

\section{LIMITATIONS TO THE STUDY}

One limitation to this study is that the study focuses on only four lessons and thus does not explore student gains over a longer period, such as an academic quarter or year. Also, this study does not address the motivations of students as individuals, but simply treats them as a group. Nevertheless, by using both groups $\mathrm{A}$ and $\mathrm{B}$ for both the Natural Approach and the ALM lessons, the chance grouping of more motivated students in one experimental group was avoided.

A further limitation to this study is that pre-test, test and post-test consisted solely of a written test and that students were informed that the aforementioned pre-test, test and post-test did not count for or against their course grade (as was required by Oregon State University administrators). It is arguable that test and post-test results could have been different if the students had taken the aforementioned tests as part of a course grade. (Making the tests part of the course grade, however, would not have been ethical due to the nature of the experimental hypotheses, which favored the Natural Approach over the ALM.)

Examination of the data reveals further limitations to this study. First of all, there 
may have been a ceiling effect with regards to certain test scores. Subjects who scored high on the pre-test were able to show little, if any, improvement. Although there were not many such instances, it is nevertheless conceivable that true variance was not measured in the case of such students.

It is noted that there were several students who were absent and thus missed either a test or a post-test. Whereas the number of such students was not great and probably did not affect results due to the large size of the two experimental groups, it is nevertheless a factor to be considered.

Further examination of test results revealed that post-test mean scores were in actuality higher than test mean scores. One would assume that long term retention would decrease as measured with short term test mean scores, but this was not the case in this study. There are several possible explanations which could conceivably have caused this phenomenon. One likely explantion is that the post-tests were administered together with the final exams. The students were aware that the post-test would not count towards their final grades, yet it is possible that there was a 'carry-over' effect from the final exam. The students could have taken the post-test more seriously as they were very concemed with the accompanying final exam score. Another explanation could stem from the fact that all concepts in Spanish are not mutually exclusive and that similar conceptual ideas were reviewed for the final exam. (The post-test content material was not covered on the final exam or on any other Spanish 111 exam. Experimental content material was separate and not covered in the regular SPN 111 course due to ethical as well as experimental design concerns.) The students were also more prepared mentally 
for any kind of test as it was the final exam week. Finally, a further explanation for higher post-test scores could be the Practice Effect in which a similar test is given to determine changes in student gains (Brown,1988). The pre-test, test and post-test were not identical in content material but were identical in format and design. It is conceivable that students could have become 'used to' the test design and thus could have improved as a result.

Another limitation to this study is that it tested students' L2 gains only on written tests. If a listening comprehension test, reading test or speaking test were incorporated into this experiment, there would have existed the opportunity to measure teaching method as a variable in regard to different components of L2 performance (i.e., speaking, listening, reading).

\section{RECOMMENDATIONS FOR FURTHER STUDY}

The data do not support the hypothesis that the Natural Approach is superior to the ALM in terms of quantifiable student L2 gains. Nevertheless, data were collected on the basis of four individual class presentations involving two ALM design lessons as well as two Natural Approach design lessons. It would thus be interesting to conduct a similar study in which random groups of students were taught using both the ALM and the Natural Approach over a longer period, such as an academic quarter or an academic year. Such a research project could investigate the possibility of a 'cumulative' effect on quantifiable student L2 gains due to teaching method.

Another recommendation for further study would be to randomly select subjects 
according to different age and educational levels in order to investigate whether the Natural Approach has an effect on student L2 gains within certain groups. This research project, for example, utilized subjects from a university level Spanish class. It would be interesting to do a similar study with younger students, especially those in the formative years of elementary school. Given the differences in students' motivations and linguistic development, it would be interesting to see if the results of such a study would differ from the results of this study. Also, it would be interesting to examine individual test scores in order to see how teaching method affected certain individual subjects.

This study used written pre-tests, tests and post-tests in order to obtain data on student L2 gains. It would therefore be worthwhile to conduct a similar experiment using a quantifiable listening comprehension/speaking test such as the American Council of Foreign Language Teachers (ACTFL) Oral Proficiency Interview (OPI) test. This test sets specific guidelines for $\mathrm{L} 2$ oral proficiency, and those individuals trained and certified by ACTFL as oral proficiency interviewers should be able to pinpoint L2 students' proficiency with a high degree of accuracy (Bymes \& Thompson,1989). Students who underwent an academic quarter or year being subjected to either the Natural Approach or the ALM could be pre-tested with an Oral Proficiency Interview and then later be post-tested by the OPI by the same interviewer. It would be interesting to see if data from such an experiment would support the Natural Approach as superior in student L2 gains using a listening/speaking proficiency measure. 


\section{CONCLUSIONS AND IMPLICATIONS}

Each individual instructor has a unique style of teaching just as each group of students has individual needs, motivations and preferences. The outcome of this study suggests that it would not be unethical for an instructor to use a mixure of ALM exercises together with a communicative approach such as the Natural Approach in which comprehensible input is used as the basis of the course design. Within the framework of a communicative course, a L2 instructor could include, if he/she chose to do so, certain exercises of an ALM design which could be helpful depending upon the needs of students and the particular classroom circumstances. Occasional use of pronunciation exercises, minimal pair drills, dialogs and pattern drills, all common to the ALM, could be incorporated into an eclectic L2 design based on a design which stresses comprehensible input. The results of this study imply that quantitative student L2 gains would not be affected, regardless of teaching method.

Much further research needs to be done regarding the ALM and the Natural Approach, especially in the area of listening comprehension/speaking gains, but until such research is complete, a L2 instructor will have to rely on individual choice as to what teaching method would be best for each specific group of L2 students. 


\section{REFERENCES}

Asher,J. (1982). Learning another language through actions: The complete teacher's guidebook. Los Gatos, CA: Sky Oaks Productions.

Brown,J.D. (1988). Understanding research in second language leaming: A teacher's guide to statistics and research design. Cambridge, UK: Cambridge University Press.

Brown,H.D. (1987). Principles of language learning and teaching. Englewood Cliffs, NJ: Prentice Hall.

Brock,C.,Crooke,G.,Day,R. \& Long,M. (1986). The differential effects of corrective feedback in native speaker-nonnative speaker conversation. In Day,R. (Ed.), Talking to Learn: Conversation in a Second Language (pp.229-236). Rowley, MA: Newbury House.

Brooks,N. (1964). Language and language learning. New York: Harcourt, Brace \& World.

Buck,K.,Bymes,H. \& Thompson,I. (1989). The American Council of Teachers of Foreign Languages oral proficiency interview tester training manual. Yonkers, NY: American Council of Teachers of Foreign Languages.

Campbell,R.N. (1979). Linguistic and social aspects of communicative competence. In Celce-Murcia,M. \& McIntosh,L. (Eds.), Teaching English as a Second or Foreign Language (pp.83-89). Rowley, MA: Newbury House.

Celce-Murica,M. \& Prator,C.H. (1979). An outline of language teaching approaches. In Celce-Murcia,M. \& McIntosh,L. (Eds.), Teaching English as a Second or Foreign Language (pp.3-5). Rowley, MA: Newbury House.

Chastain,K. (1976). Developing second language skills: Theory and practice. Chicago: Rand Mcnally.

Chamot,A. (1985). A synthesis of current literature on English as a second language: Issues for educational policy. (ERIC Document Reproduction Service No. ED261537). 
Curran,C. (1976). Couseling-learning in second languages. Apple River, WI: Apple River Press.

Dogget,G. (1986). Eight approaches to language teaching. (ERIC Document Reproduction Service No. ED272280).

Donovan,L.G. (1985). A critical view of the Natural Approach. Selecta,6,56-60.

Garman,N.B. (1986). Cinical supervision: Quackery or remedy for professional development. Journal of Curriculum and Supervision, 1, \#2, 148-157.

Gattegno,C. (1972). Teaching foreign languages in schools: The Silent Way. New York: Educational Solutions.

Hammond, R. (1988). Accuracy vs. communicative competency: The acquisition of grammar in the second language classroom. Hispania, 71,408-417.

Hatch,E. \& Lazarton,A. (1991). The research manual: Design and statistics for Applied Linguistics. New York, NY: Newbury House.

Higgs,T.V. \& Clifford,R. (1982). The push toward communication. The American Council for Teachers of Foreign Languages Foreign Language Education Series, 13. Lincolnwood, IL: National Texbooks.

Kessler,C. \& Quinn,M.E. (1984). Second language acquisition in the context of science experiences. (ERIC Document Reproduction Service No. ED248713).

Krashen,S. (1987). Application of psycholinguistic research to the classroom. In Long,M.H. \& Richards.J.C. (Eds.). In Methodology in TESOL: A book of readings (pp.33-44). New York: Newbury House.

Krashen,S. (1990). Content-based language teaching: Sheltered subject matter. Cross Currents, 18, 183-189.

Krashen,S. (1991). The input hypothesis: An update. In Georgetown University Round Table on Languages and Linguistics. Washington, DC: Georgetown University Press, 409-431.

Krashen,S. \& Terrell,T.D. (1983). The Natural Approach: Language acquisition in the classroom. Englewood Cliffs, NJ: Prentice Hall.

Lado,R. (1964). Language teaching: A scientific approach. New York: Mcgraw-Hill. 
Larsen-Freeman,D. (1979). Issues in the teaching of grammar. In Celce-Murcia,M. \& McIntosh,L. (Eds.), Teaching English as a Second or Foreign Language (pp.217-228). Rowley, MA: Newbury House.

Long,M.H. \& Richards, J.C.(Eds.). (1987). Methodology in TESOL: A book of readings. New York, NY: Newbury House.

Lozanov,G. (1979). Suggestology and outlines of Suggestopedia. New York, NY: Gordon and Brech. 1

Martin-Molero,F. (1984). Relationships between the teacher, the leamer and methods in foreign tanguage teaching: Some basic considerations. (ERIC Document Reproduction Service No. ED273103).

Mayer, R. (1985). A use of the Natural Approach in a beginning level English as a Foreign Language class in Barcelona, Spain. (ERIC Document Reproduction Service No. ED306769).

Newton,A.C. (1979). Current trends in language teaching. In Celce-Murcia,M. \& McIntosh,L. (Eds.), Teaching English as a Second or Foreign Language (pp.17-35). Rowley MA: Newbury House.

Nicola,M. (1990). Experimenting with the new methods. Dialog on Language Instruction, 6,61-72.

Oller,J.W. (1979). Language tests at school. New York, NY: Longman.

Parkin,M. (1981). The relevance of interlanguage and pidginization to French immersion schooling: Ottawa Board of Education Research Center. (ERIC Document Reproduction Service No. ED230033).

Ramirez,A. \& Stromquist,N. (1979). ESL methodology and student language learning in bilingual education schools. TESOL Quarterly, 13,145-158.

Richard-Amato,P. (1988). Making it happen. New York, NY: Longman.

Richards,J.C. \& Rogers,T. (1987). Method: Approach, design and procedure. In Long,M.H. \& Richards, J.C. (Eds.), Methodology in TESOL: A book of readings (pp.145-157). New York, NY: Newbury House.

Samimy, K.K. (1990). A comparative study of teaching Japanese in the ALM and the Couseling-Learning Approach. Modern Language Journal, 73, 169-177. 
Savignon,S. (1982). Three Americans in Paris: A look at 'natural' second language acquisition. Modern Language Journal,65,241-247.

Savignon,S. (1983). Communicative competence: Theory and classroom practice, texts and contexts in second language learning. The Addison-Wesely Second Language Professional Library Series. (ERIC Document Reproduction Service No. ED227696).

Sims,W. (1989). Fossilization and learning strategies in second language acquisition. (ERIC Document Reproduction Service No. ED339195).

Spada, N. (1987). Relationships between instructional differences and learing outcomes: A process-product study of communicative language teaching. Applied Linguistics, $8,137-155$.

Swaffer,J. \& Woodward,M.S. (1978). Language for comprehension: Focus on Reading. Modern Language Journal,62,27-32.

Swain,M. (1988). Manipulating and complementing content teaching to maximize second language learning. TESL Canada, 6, 68-83.

Terrell,T.D. (1988). Avoiding fossilization in communicative approaches. Dialog on Language Instruction, 4 1-22.

Tumposky,N.R. (1984). Behavioral objectives, the cult of efficiency and foreign language learning: Are they compatible? TESOL Quarterly, 18, 295-310.

Wesche,M.B. (1987). Communicative testing in a second language. In Long,M.H. \& Richards J.C. (Eds.), Methodology in TESOL: A book of readings (pp.373-394). New York, NY: Newbury House.

Yeats, G. (1985). Pragmatic catalysts for communicative competence: Social interfacing and consequences. (ERIC Document Reproduction Service No. ED270996). 
APPENDIX A

SAMPLE NATURAL APPROACH LESSON PLAN 


\section{NATURAL APPROACH LESSON PLAN FOOD NOV. 2,3 1992}

MATERIALS: Plastic fruits and vegetables/empty soup cans/pictures and ads of foods. These items will be available in Kidder 210. Please ask the secretary for these materials and be sure to return them after the class.

The 'La Pampa' menus will be passed out during the Friday training session.

EXERCISE 1: First the instructor will take out the plastic fruits and vegetables and soup cans one by one and will say what they are in Spanish. Then the instructor will hand an item to a student so that each student has one item. TPR EXERCISE: When the instructor calls the name of a certain food the student who holds the food item will stand. The instructor will continue to do so randomly until all students have stood up several times [as modeled on Friday]. Then, the students will exchange food items as directed by the instructor. ex: The student with food item A stands. Then the student with food item B stands. They then make the exchange and sit down. These exchanges will be repeated until all students have exchanged food items several times [as modeled on Friday].

EXERCISE 2: The instructor will pass out Spanish menus so that each student has one. The instructor will then go over each food item on the menu and will show a picture of each food item which was not seen in EX. 1. [Please do as modeled]. Each student will thus have a menu item. -REPEAT EX. 1 PROCEDURE.

EXERCISE 3: The instructor will then explain what she/he wants and will order using the verbs 'pedir' and 'querer'. This must be done, however, as a mini-drama as if the instructor were deciding and then ordering with an 'imaginary' waiter. Please do as is modelled during our Friday training session.

EXERCISE 4: ROLE-PLAY. One student will be the waiter and one student will be the restaurant patron. The role-play will be done in pairs and will be done several times with different partners. Please note that the waiter must write down what was ordered on paper and read back what was ordered [as modeled].

-Please do not forget to collect menus at the end of the class as you will need them for the next group of students.

-Also, please recall that there will be an observer in your classroom as I mentioned on Friday. 
APPENDIX B

SAMPLE ALM LESSON PLAN 
MATERIALS: Tape recorder and Dialogo 2 tape will be available at Kidder 210. Ask the secretary to let you have these materials and return them to her when the lesson is completed. session.

-Diologo 2 sheets. These will be passed out to you during the Friday training

1. Students will listen to the taped dialog three times. As they listen the will follow along with the written DIALOGO 2 sheet.

2. REPETITION. Take small parts of the dialog and have the students repeat as I will show you in our Friday training session. Be careful that the students pronounce properly. Be sure to correct any mistakes!

3. Students will then get into groups of three and read the dialog. One student will read the part of Carmen; one the part of Jose Luis; and one the part of the waiter.

4. The instructor will then have the students repeat in unison several times the verbs QUERER and PEDIR (as modelled in our Friday training session.)

5. EXERCISE. Repeat $2 \mathrm{x}$ as follows:

Yo pido la ensalada mixta.

Then say: pido la ensalada mixta.

The students will then say the sentence filling in the missing pronoun 'yo'.

Do the aforementioned for the following:

1. Tú pides la ensalada mixta.

2. El

3. Ella

4. Nosostros

5. Vosostros 
6. Ellos

7. Ellas

8. Ustedes

9. Yo quiero una ensalada mixta.

10. Tú " "

11. El "

12. Ella

13. Ud.

14. Nosotros

15. Vosotros

16. Ellos

17. Ustedes

( Do this exercise once in unison and twice individually as modeled)

EXERCISE. Repeat $2 \mathrm{x}$ as follows:

Yo pido la ensalada mixta.

Then say: Yo ___ la ensalada mixta.

Do the aforementioned for the following:

COPY EX 1-17 ONLY OMIT THE VERB! (AS MODELED!)

$1 \mathrm{x}$ in unison; $2 \mathrm{x}$ individually

7. EXERCISE. Repeat $2 \mathrm{x}$ as follows:

Quiero pedir una ensalada mixta.

Then you say: sopa de guisantes

The students then say: Quiero pedir sopa de guisantes

Do the aforementioned for the following: (Please add articles where appropriate!)

café con leche

jugo de naranja

vino blanco 
limonada

agua mineral

chuletas de cerdo

pollo asado

carne de res

pescado

flan

helados

manzana

queso

ensalada de repollo

ensalada mixta

lechuga y aceitunas

ensalada de frutas

gazpacho

sopa de guisantes

sopa de pollo

crema de esparragos

espárragos

coliflor

habichuelas

maiz tierno Now repeat this ex. $2 \mathrm{x}$ as modeled

Please remember to collect the DIALOGO 2 sheets as you will need them for your next group of students.

Also, please recall that there will be an observer in your classroom as I mentioned on Friday.

\section{DIALOGO 2 EN EL RESTAURANTE}

C: Tengo hambre, Jose Luís.

JL: Sí, yo tengo hambre tambien. ¿Quieres pedir el menú?

C: Sí, Quiero ver el menú.

JL: ¡Camarero! Queremos ver el menú, por favor.

CAM: Sí, como no. Aquí tienen. ¿Y quieren ustedes tomar algo?

JL: ¿Qué tienen de tomar?

CAM: Tenemos agua mineral, limonada, café con leche, vino blanco y jugo de naranja. JL: Carmen, ¿qué pides? 
C: Yo pido una limonada.

JL: Y vino blanco para mí.

CAM: Muy bien. ¿Y quieren pedir la ensalada ahora?

JL: Sí, una ensalada mixta para mí.

C: Y yo quiero ensalada de frutas.......no,.... de lechuga y aceitunas....no,no....una ensalada de repollo.

CAM: Sí.

C: ¿Y Jose Luís, pides sopa?

JL: Sí. Tienen gazpacho, sopa de guisantes sopa de pollo y crema de espárragos. Pido gazpacho.

C: ¿Y carne?

JL: Este... Tienen chuletas de cerdo, pollo asado, carne de res, y el pescado del dia. Tambien tienen legumbres. Hay espárrago, colflor, habichuelas y maiz tierno. ¡No sé que pedir!

C: ¡No sé tampoco!

\section{AFTER THE MEAL}

CAM: ¿Quieren ustedes postre? Tenemos flan, helados, manzanas y quesos.

C Y JL: ¡No, no queremos postre!

JL: La cuenta, por favor.

C: Jose Luís, este restaurante no es muy bueno.

JL: Sí, no es muy bueno.

\section{DIALOGO 2 IN THE RESTAURANT (ENGLISH TRANSLATION)}

C: I'm hungry, Jose Luis.

JL: Yes. I' $m$ also hungry. Do you want to ask for the menu?

C: Yes. I want to see the menu.

JL: Waiter! We want to see the menu,please.

W: Yes, of course. Here they are. Do you want something to drink?

JL: What do you have to drink?

W: We have mineral water, lemonade, coffee and milk, white wine and orange juice.

$\mathrm{JL}$ : Carmen, what are you going to order?

C: I'll order a lemonade.

JL: A white wine for me.

W: Very well. Would you like to order a salad now?

JL: Yes. A mixed salad for me.

C: And I want a fruit salad.....no, a lettuce and olive....no, no... a cabbage sadad.

W: Yes.

C: And Jose Luis, are you ordering soup?

JL: Yes. They have gazpacho, pea soup, chicken soup and creme of asparagus. I' ll 
order gazpacho.

C: And a meat dish?

JL: Yes. They have pork chops, roast chicken, beef and fish of the day. They also have vegetables. There is asparagus, cauliflower, green beans and tender corn. Hmmm....I don't know!

C: I don't know either!

\section{AFTER THE MEAL}

W: Would you like dessert? We have custard, ice cream, apples and cheeses.

JL AND C: NO! We don't want dessert!

JL: The check, please.

C: Jose Luis, this restaurant is not very good.

JL: You can say that again! 
APPENDIX C

INFORMED CONSENT FORM 


\section{INFORMED CONSENT}

I, hereby agree to serve as a subject in the research project on the investigation of the Natural Approach and the Audiolingual

Method: A question of student gains and retention, conducted under the supervision of Jeffrey Richards.

I understand that the study involves the administration of lessons following the ALM and the Natural Approach to the students enrolled in my conversant sections. I understand that in order to conduct this experiment, I will have to learn, practice and carry out lessons prepared by Jeffrey Richards which follow the ALM and the Natural Approach. I also understand that an 'observer' will be in my class to make notes in order to verify that the appropriate lesson plan and method was indeed carried out.

I may not receive any direct benefit from participation in this study, but my participation may help to increase knowledge which may benefit others in the future.

Jeffrey Richards has offered to answer any questions I may have about the study and what is expected of me in the study.

I understand that I am free to withdraw from participation in this study at any time without jeopardizing my position at Oregon State University.

I have read and understand the foregoing information and agree to participate in this study.

Date: Signature 


\section{APPENDIX D}

PRE-TEST 1 (LESSONS 1 AND 2) 
PRE-TEST QUIZ SPN $111 \quad$ Oct. 27, 1992

NAME

CONVERSANT TIME

Conversant Instructor

Fill in the blanks with the correct form of the verb "pedir".

¿___ tú el menú o yo? ¿Qué mucho pero ellos no ella y que

el? Nosotros demasiado!

Give FOUR examples of the following:

Bebidas:

Carnes:

Postres:

Legumbres:

How would you do the following in Spanish?

1. Order a sadad.

2. Ask for dessert.

3. Ask for the check.

Imagine that you are showing a Spanish speaking friend around your house. You will thus write in Spanish: This is the (room or item) or These are the (rooms or items) for the following: the carpet, the bedroom, the refridgerators, the living rooms. Please use complete sentences! (you may use the back of your paper for this exercise.) 
APPENDIX E

PRE-TEST II (LESSONS 3 AND 4) 
PRE-TEST QUIZ SPN $111 \quad$ NOV. 12, 1992

Name

CONVERSANT TIME

CONVERSANT INSTRUCTOR

1. Suppose you were in a city in Costa Rica. How would you ask someone in Spanish the location of the following: the bus stops, the shoe shop, the church, the central and national banks and the movie theater? (EXAMPLE: Where is the ?)

2. How would you give a person directions in Spanish to the post office if the post office were three blocks straight ahead, two blocks to the right, and one block to the left?

3. How would you tell a doctor in Spanish you were suffering from the following: a headache, a sore throat, sore ears, a sore knee and a sore nose? (EXAMPLE: My throat, nose, head, etc. hurts.) 


\section{APPENDIX F}

TEST I (LESSONS 1 AND 2) 
QUIZ SPN $111 \quad$ NOV. 5, 1992

NAME

CONVERSANT TIME

CONVERSANT INSTRUCTOR

Fill in the blanks with the correct form of the verb 'pedir'.

¿_usted el menú o mucho pero nosotros no yo? ¿Qué nada. ¡Vosotros tú y qué el? Ellos demasiado!

Give FOUR examples of the following in Spanish:

Ensaladas:

Carnes:

Sopas:

Legumbres:

How would you do the following in Spanish?

1. Order a drink.

2. Ask for dessert.

3. Ask for a menu.

Imagine that you are showing a Spanish speaking friend around your house. You will thus write in Spanish: This is the (room or item) or These are the (rooms or items) for the following: the couch, the kitchen, the cofee tables and the bedrooms. Please use complete sentences! (You may use the back of you paper for this exercise.) 


\section{APPENDIX G}

TEST II (LESSONS 3 AND 4) 
QUIZ SPN $111 \quad$ NOV. 24,1992

NAME

CONVERSANT TIME

CONVERSANT INSTRUCTOR

1. Suppose you were in a city in Costa Rica. How would you ask someone in Spanish the location of the following: the post office, the consulates, the repair shop, the movie theater and the restaurants? (EXAMPLE: Where is the ?)

2. How would you give directions in Spanish to the post office if the post office were one block straight ahead, three blocks to the left, and two blocks to the right?

3. How would you tell a doctor in Spanish that you were suffering from the following: a backache, a sore arm, sore shoulders, a sore hand and a sore leg? (EXAMPLE: My back, arm, hand, etc. hurts.) 


\section{APPENDIX H}

POST-TEST I (LESSONS 1 AND 2) 
$\begin{array}{lll}\text { POST-TEST I SPN } 111 & \text { Dec. 8, } 1992\end{array}$

NAME

CONVERSANT TIME

CONVERSANT INSTRUCTOR

Fill in the blanks with the correct form of the verb 'pedir'.

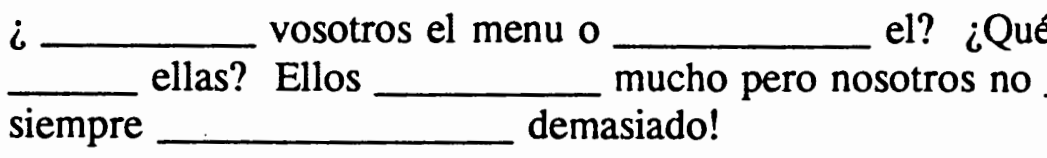
tú y qué nada. ¡Yo

Give FOUR examples of the following in Spanish:

Ensaladas:

Carnes:

Sopas:

Legumbres:

How would you do the following in Spanish?

1. Order a salad.

2. Ask for dessert.

3. Ask for the check.

Imagine that you are showing a Spanish speaking friend around your house. You will thus write in Spanish: This is the (room or item) or These are the (rooms or items) for the following: the kitchen, the bedroom, the coffee tables, and the carpets. Please use complete sentences! (You may use the back of your paper for this exercise.) 


\section{APPENDIX I}

POST-TEST II (LESSONS 3 AND 4) 
POST-TEST II $\quad$ SPN $111 \quad$ Dec. 8, 1992

NAME

CONVERSANT TIME

CONVERSANT INSTRUCTOR

1. Suppose you were in a city in Costa Rica. How would you ask someone in Spanish the location of the following: the bus stops, the banks, the repair shop, the bakery and the clothing store? (EXAMPLE: Where is the ?)

2. How would you give a person directions in Spanish to the post office if the post office were one block straight ahead, two blocks to the right, and three blocks to the left?

3. How would you tell a doctor in Spanish you were suffering from the following: a sore arm, sore feet, sore fingers, a headache and a backache? (EXAMPLE: My arm, feet, fingers, etc. hurts.) 